\title{
Winter $\mathrm{ClNO}_{2}$ formation in the region of fresh anthropogenic emissions: seasonal variability and insights into daytime peaks in northern China
}

\author{
Men Xia ${ }^{1}$, Xiang Peng ${ }^{1}$, Weihao Wang ${ }^{1,8}$, Chuan Yu ${ }^{1,2}$, Zhe Wang ${ }^{6}$, Yee Jun Tham ${ }^{7}$, Jianmin Chen ${ }^{4}$, Hui Chen ${ }^{4}$, \\ Yujing $\mathrm{Mu}^{5}$, Chenglong Zhang ${ }^{5}$, Pengfei Liu ${ }^{5}$, Likun Xue ${ }^{2}$, Xinfeng Wang ${ }^{2}$, Jian Gao ${ }^{3}$, Hong $\mathrm{Li}^{3}$, and Tao Wang \\ ${ }^{1}$ Department of Civil and Environmental Engineering, The Hong Kong Polytechnic University, Hong Kong SAR, China \\ ${ }^{2}$ Environment Research Institute, Shandong University, Ji'nan, Shandong, China \\ ${ }^{3}$ Chinese Research Academy of Environmental Sciences, Beijing, China \\ ${ }^{4}$ Department of Environmental Science and Engineering, Institute of Atmospheric Sciences, \\ Fudan University, Shanghai, China \\ ${ }^{5}$ Research Center for Eco-Environmental Sciences, Chinese Academy of Sciences, Beijing, China \\ ${ }^{6}$ Division of Environment and Sustainability, Hong Kong University of Science and Technology, Hong Kong SAR, China \\ ${ }^{7}$ Institute for Atmospheric and Earth System Research/Physics, University of Helsinki, Helsinki, Finland \\ ${ }^{8}$ Hangzhou PuYu Technology Development Co., Ltd, Hangzhou, Zhejiang, China
}

Correspondence: Tao Wang (cetwang@polyu.edu.hk)

Received: 3 February 2021 - Discussion started: 8 March 2021

Revised: 19 July 2021 - Accepted: 27 September 2021 - Published: 27 October 2021

\begin{abstract}
Nitryl chloride $\left(\mathrm{ClNO}_{2}\right)$ is an important chlorine reservoir in the atmosphere that affects the oxidation of volatile organic compounds (VOCs) and the production of $\mathrm{RO}_{x}$ radicals and ozone $\left(\mathrm{O}_{3}\right)$. This study presents measurements of $\mathrm{ClNO}_{2}$ and related compounds at urban, polluted rural, and polluted lower tropospheric (mountaintop) sites in the winter of 2017-2018 over the North China Plain (NCP). The nocturnal concentrations of $\mathrm{ClNO}_{2}$ were lower at the urban and polluted rural sites but higher at the polluted lower tropospheric site. The winter concentrations of $\mathrm{ClNO}_{2}$ were generally lower than the summer concentrations that were previously observed at these sites, which was due to the lower nitrate radical $\left(\mathrm{NO}_{3}\right)$ production rate $\left(P\left(\mathrm{NO}_{3}\right)\right)$ and the smaller $\mathrm{N}_{2} \mathrm{O}_{5}$ uptake coefficients $\left(\gamma\left(\mathrm{N}_{2} \mathrm{O}_{5}\right)\right)$ in winter, despite the higher ratios of dinitrogen pentoxide $\left(\mathrm{N}_{2} \mathrm{O}_{5}\right)$ to $\mathrm{NO}_{3}$ in winter. Significant daytime peaks of $\mathrm{ClNO}_{2}$ were observed at all the sites during the winter campaigns, with $\mathrm{CINO}_{2}$ mixing ratios of up to $1.3 \mathrm{ppbv}$. Vertical transport of $\mathrm{ClNO}_{2}$ from the residual layers and prolonged photochemical lifetime of $\mathrm{ClNO}_{2}$ in winter may explain the elevated daytime concentrations. The daytime-averaged chlorine radical $(\mathrm{Cl})$ production rates $(P(\mathrm{Cl}))$ from the daytime $\mathrm{ClNO}_{2}$ were
\end{abstract}

$0.17,0.11$, and $0.12 \mathrm{ppbv} \mathrm{h}^{-1}$ at the polluted rural, urban, and polluted lower tropospheric sites, respectively, which were approximately 3-4 times higher than the campaign-averaged conditions. Box model calculations showed that the $\mathrm{Cl}$ atoms liberated during the daytime peaks of $\mathrm{ClNO}_{2}$ increased the $\mathrm{RO}_{x}$ levels by up to $27 \%-37 \%$ and increased the daily $\mathrm{O}_{3}$ productions by up to $13 \%-18 \%$. Our results provide new insights into the $\mathrm{ClNO}_{2}$ processes in the lower troposphere impacted by fresh and intense anthropogenic emissions and reveal that $\mathrm{ClNO}_{2}$ can be an important daytime source of $\mathrm{Cl}$ radicals under certain conditions in winter.

\section{Introduction}

$\mathrm{Cl}$ is a potent atmospheric oxidant that reacts analogously to hydroxyl radicals $(\mathrm{OH})$ with hydrocarbons (Simpson et al., 2015). $\mathrm{Cl}$ is highly reactive toward alkanes, with the rate constants of its reactions with alkanes being approximately 10-200 times greater than some of the $\mathrm{OH}+\mathrm{VOC}$ reactions (Atkinson and Arey, 2003; Young et al., 2014; Burkholder et al., 2015). Consequently, $\mathrm{Cl}$ enhances the production of $\mathrm{RO}_{x}$ 
$\left(=\mathrm{OH}+\mathrm{HO}_{2}+\mathrm{RO}_{2}\right)$ via Reactions (R1)-(R4), which promotes $\mathrm{O}_{3}$ formation by converting nitric oxide (NO) to nitrogen dioxide $\left(\mathrm{NO}_{2}\right)$ (Reactions $\mathrm{R} 3$ and $\left.\mathrm{R} 5\right)$. $\mathrm{Cl}$ also consumes $\mathrm{O}_{3}$ via Reaction (R8). The net effect of the $\mathrm{Cl}$ chemistry is typically the depletion of $\mathrm{O}_{3}$ in the remote atmosphere, such as the stratosphere (Molina and Rowland, 1974) and remote oceans (Simpson et al., 2015; Wang et al., 2019), and an increase in $\mathrm{O}_{3}$ production in the polluted troposphere (Riedel et al., 2014; Xue et al., 2015).

$$
\begin{aligned}
& \mathrm{RH}(g)+\mathrm{Cl}(g) \rightarrow \mathrm{R}(g)+\mathrm{HCl}(g) \\
& \mathrm{R}(g)+\mathrm{O}_{2}(g)+\mathrm{M} \rightarrow \mathrm{RO}_{2}(g)+\mathrm{M} \\
& \mathrm{RO}_{2}(g)+\mathrm{NO}(g) \rightarrow \mathrm{RO}(g)+\mathrm{NO}_{2}(g) \\
& \mathrm{RO}(g)+\mathrm{O}_{2}(g) \rightarrow \mathrm{HO}_{2}(g)+\text { products } \\
& \mathrm{HO}_{2}(g)+\mathrm{NO}(g) \rightarrow \mathrm{OH}(g)+\mathrm{NO}_{2}(g) \\
& \mathrm{NO}_{2}(g)+h v \rightarrow \mathrm{NO}(g)+\mathrm{O}\left({ }^{3} \mathrm{P}\right) \\
& \mathrm{O}_{2}(g)+\mathrm{O}\left({ }^{3} \mathrm{P}\right)+\mathrm{M} \rightarrow \mathrm{O}_{3}(g)+\mathrm{M} \\
& \mathrm{Cl}(g)+\mathrm{O}_{3}(g) \rightarrow \mathrm{ClO}(g)+\mathrm{O}_{2}(g)
\end{aligned}
$$

Here $\mathrm{M}$ denotes the third body in ambient air.

The production of $\mathrm{Cl}$ is determined by the formation and decomposition of $\mathrm{Cl}$ precursors such as $\mathrm{ClNO}_{2}$ (Chang et al., 2011; Simpson et al., 2015). $\mathrm{ClNO}_{2}$ is produced mostly in dark conditions by the heterogeneous uptake of $\mathrm{N}_{2} \mathrm{O}_{5}$ on chloride $\left(\mathrm{Cl}^{-}\right)$-laden aerosols (Reactions R9-R13) and undergoes photolysis during the day (Reaction R14) (Finlayson-Pitts et al., 1989). $\mathrm{ClNO}_{2}$ formation is constrained by the $\mathrm{NO}_{3}$ production rate $\left(P\left(\mathrm{NO}_{3}\right)\right.$, Reaction R9). $\mathrm{NO}_{3}$ is in thermal equilibrium with $\mathrm{N}_{2} \mathrm{O}_{5}$ (Reaction R10), and the equilibrium constant $\left(K_{\text {eq }}\right)$ depends on temperature and $\mathrm{NO}_{2}$ concentrations. $\mathrm{N}_{2} \mathrm{O}_{5}$ formation is suppressed by $\mathrm{NO}$ and VOCs as they consume $\mathrm{NO}_{3}$ (Reactions R11-12). The $\mathrm{N}_{2} \mathrm{O}_{5}$ uptake probability $\left(\gamma\left(\mathrm{N}_{2} \mathrm{O}_{5}\right)\right)$ and $\mathrm{ClNO}_{2}$ production yield $\left(\varphi\left(\mathrm{ClNO}_{2}\right)\right)$ are kinetic parameters with values between 0 and 1 , which can be derived from the observation data of $\mathrm{N}_{2} \mathrm{O}_{5}, \mathrm{ClNO}_{2}$, and related species (Brown et al., 2006; Phillips et al., 2016). Previous laboratory studies have demonstrated that $\gamma\left(\mathrm{N}_{2} \mathrm{O}_{5}\right)$ is enhanced by higher relative humidity (RH) and particulate $\mathrm{Cl}^{-}$concentrations but suppressed by higher temperature and concentrations of aerosol nitrate $\left(\mathrm{NO}_{3}^{-}\right)$and organic species (Behnke et al., 1997; Hallquist et al., 2003; Bertram et al., 2009; Griffiths and Anthony Cox, 2009).

$$
\begin{aligned}
& \mathrm{NO}_{2}(g)+\mathrm{O}_{3}(g) \rightarrow \mathrm{NO}_{3}(g)+\mathrm{O}_{2}(g) \\
& \mathrm{NO}_{3}(g)+\mathrm{NO}_{2}(g) \leftrightarrow \mathrm{N}_{2} \mathrm{O}_{5}(g) \\
& \mathrm{NO}_{3}(g)+\mathrm{NO}(g) \leftrightarrow 2 \mathrm{NO}_{2}(g) \\
& \mathrm{NO}_{3}(g)+\mathrm{VOCs}(g) \rightarrow \text { products } \\
& \mathrm{N}_{2} \mathrm{O}_{5}(g)+\mathrm{Cl}^{-}(\mathrm{aq}) \rightarrow \mathrm{ClNO}_{2}(\mathrm{~g})+\mathrm{NO}_{3}^{-}(\mathrm{aq}) \\
& \mathrm{ClNO}_{2}(g)+h v \rightarrow \mathrm{Cl}(g)+\mathrm{NO}_{2}(g)
\end{aligned}
$$

Field observations of $\mathrm{ClNO}_{2}$ were first reported in the marine boundary layer off the coast of the Houston-Galveston area in the United States (Osthoff et al., 2008). Subsequent studies demonstrated the worldwide ubiquity of $\mathrm{ClNO}_{2}$ and confirmed its significant role in photochemistry (Thornton et al., 2010; Mielke et al., 2011; Phillips et al., 2012; Edwards et al., 2013; Bannan et al., 2015; Wild et al., 2016; Wang et al., 2016; Bannan et al., 2019; Eger et al., 2019). The role of $\mathrm{ClNO}_{2}$ in the radical budget could be more important than that of $\mathrm{OH}$ in winter, because $\mathrm{OH}$ production is reduced in winter owing to lower concentrations of $\mathrm{O}_{3}$ and $\mathrm{H}_{2} \mathrm{O}$ vapor in this season. A limited number of winter observations of $\mathrm{ClNO}_{2}$ have been conducted on various platforms, including on aircraft over northern Europe (Priestley et al., 2018) and the eastern United States (Haskins et al., 2018, 2019); on a tall tower in Boulder, United States (Riedel et al., 2013); on a mountaintop in Hong Kong (Wang et al., 2016); and at ground sites in Alberta, Canada (Mielke et al., 2016), and Heshan, China (Yun et al., 2018). These studies found high $\mathrm{ClNO}_{2}$ mixing ratios of up to $7.7 \mathrm{ppbv}$ (Yun et al., 2018) in winter and a contribution of $\mathrm{ClNO}_{2}$ to $\mathrm{Cl}$ liberation of up to $83 \%$ (Priestley et al., 2018) in urban Manchester, and that $\mathrm{ClNO}_{2}$ was a more dominant radical source than $\mathrm{OH}$ in both the early morning and the whole day in the polluted marine boundary layer downwind of the northeast United States (Haskins et al., 2019). $\mathrm{ClNO}_{2}$ usually exhibits higher concentrations in aged and polluted air masses than in clean air and in regions subject to significant fresh $\mathrm{NO}$ emissions (Wang et al., 2016; Z. Wang et al., 2017; Osthoff et al., 2018).

The chemical production of $\mathrm{ClNO}_{2}$ in winter has some unique features compared with that in warmer seasons. Long winter nights provide more time for $\mathrm{ClNO}_{2}$ production and accumulation. Lower temperatures in winter shift the $\mathrm{N}_{2} \mathrm{O}_{5}-$ $\mathrm{NO}_{3}$ equilibrium to the $\mathrm{N}_{2} \mathrm{O}_{5}$ side (Brown et al., 2003) and increase the $\gamma\left(\mathrm{N}_{2} \mathrm{O}_{5}\right)$ on aerosols (Bertram and Thornton, 2009). In addition, $\mathrm{NO}_{x}$ has longer lifetimes in winter compared with summer due to less abundant $\mathrm{OH}$ radicals in winter and its slower reaction rate with $\mathrm{OH}$ (Kenagy et al., 2018). However, $P\left(\mathrm{NO}_{3}\right)$ might be lower in winter due to reduced $\mathrm{O}_{3}$ concentrations. The availability of aerosol $\mathrm{Cl}^{-}$also varies in winter and summer. More $\mathrm{Cl}^{-}$is emitted due to coal burning in winter (McCulloch et al., 1999; Fu et al., 2018). In places like East Asia, the winter monsoon brings air masses from the interior of the continent, thereby suppressing the transport of sea salt to inland areas. Because of the contrasts in the availability of aerosol chloride and the variability in meteorology and $\mathrm{NO}_{x}$ emissions that affect the $\mathrm{N}_{2} \mathrm{O}_{5}$ chemistry, it is not clear whether $\mathrm{ClNO}_{2}$ formation is more prevalent in winter.

The North China Plain (NCP) - home to Beijing and several other megacities - is one of the most industrialized and populous regions of China and frequently suffers from severe haze pollution in winter (An et al., 2019; Fu et al., 2020). $\mathrm{ClNO}_{2}$ concentrations have been measured over the NCP (Le Breton et al., 2018; Zhou et al., 2018), but only one study was conducted in winter (Le Breton et al., 2018). The present study presents recent field observations of $\mathrm{ClNO}_{2}$ concentra- 
tions from three campaigns conducted in winter and early spring at three sites in the NCP. The results were compared with those obtained in the previous summer campaigns at the same locations. We examined the factors controlling $\mathrm{ClNO}_{2}$ formation, i.e., $P\left(\mathrm{NO}_{3}\right)$, which is the nocturnal reactivity of $\mathrm{NO}_{3}$, and $\mathrm{N}_{2} \mathrm{O}_{5}, \gamma\left(\mathrm{N}_{2} \mathrm{O}_{5}\right)$, and $\varphi\left(\mathrm{ClNO}_{2}\right)$. We then focused on the unexpected daytime peaks of $\mathrm{ClNO}_{2}$ concentrations that were observed at the sites and evaluated their impact on the daytime atmospheric oxidative capacity using a chemical box model.

\section{Methods}

\subsection{Observation sites}

Field campaigns were performed in Wangdu, Beijing, and Mt. Tai in sequence during the winter-early spring of 20172018 (Table 1). The locations of the three sites are shown in Supplement Fig. S1. The sites were selected for investigation of $\mathrm{ClNO}_{2}$ in urban, rural, and mountain areas of the NCP. The winter indoor-heating period lasts from early November to 15 March of the following year (Ran et al., 2016), and thus the observations were made mostly during the heating period during which coal is intensively used. Detailed descriptions of the measurement sites are available in previous studies (Tham et al., 2016; Z. Wang et al., 2017; Xia et al., 2019), and a brief introduction is given here.

Our observations at the Wangdu site were part of the Campaign of Oxidation Potential Research for air Pollution in winter (COPPER). The Wangdu site is located in Dongbaituo Village, Hebei Province. Local villagers use coal stoves for cooking and heating during winter. National road G4 and provincial road S335 are 1 and $3 \mathrm{~km}$ to the west of the sampling site, respectively. Many heavy-duty trucks passed through G4 and S335 every night during the study period, emitting a large amount of $\mathrm{NO}_{x}$ and particulate matter. Therefore, the site experienced heavy pollution from coal burning and road traffic (Peng et al., 2020).

The Beijing site is located at the Chinese Research Academy of Environmental Science (CRAES), which is $15 \mathrm{~km}$ northeast of the city center. The sampling site is surrounded by intra-city roads, commercial buildings, and residential buildings with few industrial facilities. When the prevailing wind originates from the north (i.e., remote mountainous regions), the site is upwind from the Beijing downtown area and thus is less polluted. However, when the wind originates from the south, the site receives pollutants from Beijing's urban areas in the NCP (Xia et al., 2019).

Mt. Tai is located approximately $40 \mathrm{~km}$ south of Jinan City (population: 8.9 million) and $15 \mathrm{~km}$ north of Tai' an City (population: 5.6 million) (Wen et al., 2018). Measurements were taken at Mt. Tai meteorological station (1534 m a.s.l.). The site is isolated from the anthropogenic emissions of tourist areas and is not affected by local emissions. The ob- servation period, i.e., March to April, was in early spring in the NCP. However, considering the low temperature $\left(4.6 \pm 6.3^{\circ}\right)$ observed on top of Mt. Tai, this study considered the observation period to be winter to early spring.

\subsection{Measurements of $\mathrm{N}_{2} \mathrm{O}_{5}$ and $\mathrm{ClNO}_{2}$ concentrations}

$\mathrm{N}_{2} \mathrm{O}_{5}$ and $\mathrm{ClNO}_{2}$ were simultaneously measured by a chemical ionization mass spectrometer with a quadrupole mass analyzer (Q-CIMS; THS Instruments). The principles and calibrations of the Q-CIMS measurements are available in previous studies (Wang et al., 2016; Tham et al., 2016; Z. Wang et al., 2017; Xia et al., 2019). Briefly, the primary ions used in the Q-CIMS were iodide $\left(\mathrm{I}^{-}\right)$and its water clusters, which were generated using $\mathrm{CH}_{3} \mathrm{I}$ with an inline ionizer $\left({ }^{210} \mathrm{Po}\right)$. The iodide adducts, namely $\mathrm{IN}_{2} \mathrm{O}_{5}^{-}$and $\mathrm{ICINO}_{2}^{-}$, were then detected by the mass spectrometer. An example of the mass spectrum is shown in Fig. S2. The integration time of the signals recorded by the Q-CIMS is shown in Table S1. The isotopic ratios of $\mathrm{I}^{35} \mathrm{ClNO}_{2}^{-}$and $\mathrm{I}^{37} \mathrm{ClNO}_{2}^{-}$in the ambient data were used to confirm the identity of $\mathrm{ClNO}_{2}$ (Fig. S3). Gas-phase mixtures of $\mathrm{NO}_{2}$ and $\mathrm{O}_{3}$ produced $\mathrm{N}_{2} \mathrm{O}_{5}$ for $\mathrm{N}_{2} \mathrm{O}_{5}$ calibration. The synthetic $\mathrm{N}_{2} \mathrm{O}_{5}$ was converted to $\mathrm{ClNO}_{2}$ by passage through a humidified $\mathrm{NaCl}$ slurry for $\mathrm{ClNO}_{2}$ calibration. The dependence of the $\mathrm{N}_{2} \mathrm{O}_{5}$ sensitivities on ambient $\mathrm{RH}$ was tested once in each campaign and used to calibrate the $\mathrm{N}_{2} \mathrm{O}_{5}$ data (Fig. S4a). $\mathrm{ClNO}_{2}$ sensitivities were found to be not affected by RH (Fig. S4b). Single-concentration calibrations of $\mathrm{N}_{2} \mathrm{O}_{5}$ and $\mathrm{ClNO}_{2}$ were performed every 1$2 \mathrm{~d}$, which showed stable sensitivities of $\mathrm{N}_{2} \mathrm{O}_{5}$ and $\mathrm{ClNO}_{2}$ (Text $\mathrm{S} 1$ and Fig. S5). And the linearity of the $\mathrm{N}_{2} \mathrm{O}_{5}$ and $\mathrm{ClNO}_{2}$ signals to concentrations was checked via multiconcentration calibrations in the Mt. Tai campaign (Fig. S6). Backgrounds of $\mathrm{N}_{2} \mathrm{O}_{5}$ and $\mathrm{ClNO}_{2}$ were determined by passing the ambient air through glass wool once a day at different time. The background signals of $\mathrm{N}_{2} \mathrm{O}_{5}(3.3-7.7 \mathrm{pptv})$ and $\mathrm{ClNO}_{2}(1.0-7.5 \mathrm{pptv})$ were stable and independent of the time of the day (Fig. S7). The detection limits of $\mathrm{N}_{2} \mathrm{O}_{5}$ and $\mathrm{ClNO}_{2}$ were 6.9-7.3 and 3.8-5.3 pptv, which is defined here as 3 times the standard deviation of the background signals in 5 min (Table S2 in the Supplement). A virtual-impactor design (Peng et al., 2020) was adopted, and the sampling tube was replaced daily to minimize inlet artifacts.

\subsection{Other measurements}

The trace gases, particle number size distribution (PNSD), and ionic composition of aerosols and other species were simultaneously measured (Table S3). Online non-methane hydrocarbons were measured by gas chromatography-flame ionization detection-mass spectrometry (GC-FID/MS; Chromatotec Group) at the Beijing site (Zhang et al., 2017) and Wangdu site (Zhang et al., 2020). At Mt. Tai, we used canisters to collect air samples, which were analyzed using GCFID/MS. In Wangdu and Mt. Tai, oxygenated volatile or- 
Table 1. Locations and periods of the field campaigns relevant to this study.

\begin{tabular}{|c|c|c|c|c|c|}
\hline Location/ coordinate & Site category & Season & Observation period & $\mathrm{NO}_{x}(\mathrm{ppbv})$ & $\mathrm{O}_{3}(\mathrm{ppbv})$ \\
\hline \multirow[t]{2}{*}{ Wangdu $\left(38.66^{\circ} \mathrm{N}, 115.25^{\circ} \mathrm{E}\right)$} & \multirow[t]{2}{*}{ Polluted rural } & Winter $^{1}$ & 9-31 December 2017 & $83.2 \pm 81.3$ & $4.7 \pm 4.5$ \\
\hline & & Summer $^{2}$ & 21 June to 9 July 2014 & $18.3 \pm 11.8$ & $37.8 \pm 26.2$ \\
\hline \multirow[t]{2}{*}{ Beijing $\left(40.04^{\circ} \mathrm{N}, 116.42^{\circ} \mathrm{E}\right)$} & \multirow[t]{2}{*}{ Urban } & Winter ${ }^{1}$ & 6 January to 1 February 2018 & $35.6 \pm 37.4$ & $14.5 \pm 11.5$ \\
\hline & & Early summer ${ }^{3}$ & 24 April to 31 May 2017 & $22.4 \pm 18.3$ & $27.2 \pm 20.6$ \\
\hline \multirow[t]{2}{*}{ Mt. Tai $\left(36.25^{\circ} \mathrm{N}, 117.10^{\circ} \mathrm{E}\right)$} & \multirow{2}{*}{$\begin{array}{l}\text { Polluted lower } \\
\text { troposphere }\end{array}$} & Winter to early spring 1 & 7 March to 8 April 2018 & $2.4 \pm 2.0$ & $65.1 \pm 14.1$ \\
\hline & & Summer ${ }^{4}$ & 24 July to 27 August 2014 & $3.1 \pm 3.0$ & $77.8 \pm 20.1$ \\
\hline
\end{tabular}

${ }^{1}$ Observations from this study. ${ }^{2-4}$ Observations from previous studies, i.e., Tham et al. (2016), Xia et al. (2019), and Z. Wang et al. (2017), respectively.

ganic compound (OVOC) samples were collected on DNPHcoated sorbent cartridges followed by post-campaign analysis using high-performance liquid chromatography. The ionic compositions of $\mathrm{PM}_{2.5}$ (e.g., $\mathrm{NH}_{4}^{+}, \mathrm{NO}_{3}^{-}, \mathrm{SO}_{4}^{2-}$, and $\mathrm{Cl}^{-}$) were quantified by the Monitor for AeRosols and GAses in ambient air (MARGA, Metrohm) at the Beijing and Mt. Tai sites (Wen et al., 2018). An aerosol chemical speciation monitor (ACSM, Aerodyne Research Inc.) was utilized at the Wangdu site to monitor the non-refractory components of these ions in $\mathrm{PM}_{2.5}$. The concentrations of the $\mathrm{NO}_{3}^{-}$, $\mathrm{SO}_{4}^{2-}$, and $\mathrm{NH}_{4}^{+}$measured simultaneously by the MARGA and ACSM were in good agreement, whereas the concentration of $\mathrm{Cl}^{-}$measured by the ACSM was slightly lower than that measured by the MARGA, which was possibly due to the significant proportion of refractory chloride, e.g., $\mathrm{NaCl}$, present in the aerosols (Xia et al., 2020). We assumed that the particles sampled by a wide-range particle spectrometer (WPS) were spherical in shape and calculated the aerosol surface area density $\left(S_{\mathrm{a}}\right)$ and volume density $\left(V_{\mathrm{a}}\right)$. A parameterization was adopted to consider the hygroscopic growth factor (GF) of aerosol sizes, as follows: $\mathrm{GF}=a \times\left(b+\frac{1}{1-\mathrm{RH}}\right)^{1 / 3}$ (Lewis, 2008), where the parameters $a$ and $b$ were derived as 0.582 and 8.460 , respectively, in a previous field study over the NCP (Achtert et al., 2009).

\subsection{Calculation of $\mathrm{N}_{2} \mathrm{O}_{5}$ loss and $\mathrm{ClNO}_{2}$ production}

Some analytical metrics were calculated from the observation data. $P\left(\mathrm{NO}_{3}\right)$ was calculated using Eq. (1), where $k_{1}$ represents the rate constant of Reaction (R9) (Atkinson and Lloyd, 1984).

$$
P\left(\mathrm{NO}_{3}\right)=k_{1} \times\left[\mathrm{O}_{3}\right] \times\left[\mathrm{NO}_{2}\right]
$$

$k\left(\mathrm{NO}_{3}\right)$ during the night was calculated using the measured mixing ratios of NO and non-methane hydrocarbons that were measured by GC (Sect. 2.3). As most OVOCs react with $\mathrm{NO}_{3}$ at much slower rates compared to those with hydrocarbons, especially alkenes (Atkinson and Arey, 2003), the OVOCs were not included in the calculation of $k\left(\mathrm{NO}_{3}\right)$. Nonetheless, the $k\left(\mathrm{NO}_{3}\right)$ might be slightly underestimated here.

$k\left(\mathrm{NO}_{3}\right)=\sum k_{i}\left[\mathrm{VOC}_{i}\right]+k_{\mathrm{NO}+\mathrm{NO}_{3}}[\mathrm{NO}]$,

where $k_{i}$ is the rate constant for a specific $\mathrm{VOC}+\mathrm{NO}_{3}$ reaction and is adopted from Atkinson and Arey (2003), and $k_{\mathrm{NO}+\mathrm{NO}_{3}}$ represents the rate constant for Reaction (R11) (DeMore et al., 1997). The ambient concentrations of $\mathrm{NO}_{3}$ were estimated by assuming that $\mathrm{NO}_{3}$ and $\mathrm{N}_{2} \mathrm{O}_{5}$ were in dynamic equilibrium (DeMore et al., 1997).

$\left[\mathrm{NO}_{3}\right]=\frac{\left[\mathrm{N}_{2} \mathrm{O}_{5}\right]}{\left[\mathrm{NO}_{2}\right] K_{\mathrm{eq}}}$

The loss rates of $\mathrm{NO}_{3}$ due to $\mathrm{NO}$ and VOCs were then calculated by $k_{\mathrm{NO}+\mathrm{NO}_{3}}[\mathrm{NO}]\left[\mathrm{NO}_{3}\right]$ and $\sum k_{i}\left[\mathrm{VOC}_{i}\right]\left[\mathrm{NO}_{3}\right]$, respectively.

The loss rate coefficient of $\mathrm{N}_{2} \mathrm{O}_{5}$ on the aerosol surface $\left(k\left(\mathrm{~N}_{2} \mathrm{O}_{5}\right)\right)$ is expressed as follows.

$k\left(\mathrm{~N}_{2} \mathrm{O}_{5}\right)=0.25 \times c\left(\mathrm{~N}_{2} \mathrm{O}_{5}\right) \times S_{\mathrm{a}} \times \gamma\left(\mathrm{N}_{2} \mathrm{O}_{5}\right)$,

where $c\left(\mathrm{~N}_{2} \mathrm{O}_{5}\right)$ represents the average molecular velocity of $\mathrm{N}_{2} \mathrm{O}_{5}$. The rate constants $\left(k_{1}, k_{i}\right.$, and $\left.k_{\mathrm{NO}+\mathrm{NO}_{3}}\right)$ and equilibrium constant $\left(K_{\mathrm{eq}}\right)$ are calculated as temperature-dependent parameters.

$\gamma\left(\mathrm{N}_{2} \mathrm{O}_{5}\right)$ and $\varphi\left(\mathrm{ClNO}_{2}\right)$ were estimated using steadystate analysis in applicable cases (Brown et al., 2006). This method assumes a steady state of $\mathrm{N}_{2} \mathrm{O}_{5}$, which means that the production rate of $\mathrm{N}_{2} \mathrm{O}_{5}$ is equal to its loss rate. We adopted the criteria described by Xia et al. (2020) to select the cases, namely low concentrations of NO, an increasing trend of $\mathrm{ClNO}_{2}$ concentrations, and stable air masses. Equation (5) was then established by plotting $\tau\left(\mathrm{N}_{2} \mathrm{O}_{5}\right)^{-1} \times\left[\mathrm{NO}_{2}\right] \times K_{\text {eq }}$ against $0.25 \times S_{\mathrm{a}} \times \mathrm{C}_{\mathrm{N}_{2} \mathrm{O}_{5}} \times\left[\mathrm{NO}_{2}\right] \times K_{\text {eq }}$, with $\gamma\left(\mathrm{N}_{2} \mathrm{O}_{5}\right)$ as the slope and $k\left(\mathrm{NO}_{3}\right)$ as the intercept in the linear regression (Brown et al., 2003). Here, the derived $\gamma\left(\mathrm{N}_{2} \mathrm{O}_{5}\right)$ was accepted when the regression had $R^{2}>0.5$ and $k\left(\mathrm{NO}_{3}\right)>0$.

$$
\begin{aligned}
\tau\left(\mathrm{N}_{2} \mathrm{O}_{5}\right)^{-1} & \times K_{\mathrm{eq}} \times\left[\mathrm{NO}_{2}\right] \approx 0.25 \times \mathrm{C}_{\mathrm{N}_{2} \mathrm{O}_{5}} \times S_{\mathrm{a}} \times K_{\mathrm{eq}} \\
& \times\left[\mathrm{NO}_{2}\right] \times \gamma\left(\mathrm{N}_{2} \mathrm{O}_{5}\right)+k\left(\mathrm{NO}_{3}\right)
\end{aligned}
$$

$\varphi\left(\mathrm{ClNO}_{2}\right)$ was then calculated using the following equation:

$$
\varphi\left(\mathrm{ClNO}_{2}\right)=\frac{\mathrm{d}\left[\mathrm{ClNO}_{2}\right] / \mathrm{d} t}{k\left(\mathrm{~N}_{2} \mathrm{O}_{5}\right)\left[\mathrm{N}_{2} \mathrm{O}_{5}\right]},
$$


where $d\left[\mathrm{ClNO}_{2}\right] / \mathrm{d} t$ and $\left[\mathrm{N}_{2} \mathrm{O}_{5}\right]$ represent the increasing rate of $\mathrm{ClNO}_{2}$ production and the average concentration of $\mathrm{N}_{2} \mathrm{O}_{5}$, respectively, within the selected cases.

\subsection{Box model}

An observation-based chemical box model was utilized to simulate the concentrations of $\mathrm{Cl}$ and $\mathrm{RO}_{x}$ radicals and the production and loss pathways of $\mathrm{O}_{3}$. The detailed model description is available in Peng et al. (2020). Based on Master Chemical Mechanism (MCM) v3.3.1 (Jenkin et al., 2015), Peng et al. (2020) modified the chemical mechanisms to include up-to-date gas-phase chlorine and bromine chemistry. The observed $\mathrm{N}_{2} \mathrm{O}_{5}, \mathrm{ClNO}_{2}, \mathrm{NO}_{x}, \mathrm{HONO}, \mathrm{O}_{3}, j \mathrm{NO}_{2}$, and related species were constrained in the model for every 10 min of model time, after interpolating or averaging the data (Table S4). The mixing ratios of non-methane hydrocarbons (NMHCs) and OVOCs (Sect. 2.3) were constrained every hour. As OVOCs were not measured in Beijing in this study, we adopted the concentrations of OVOCs measured in previous studies in winter Beijing (Gu et al., 2019; Qian et al., 2019). We also assumed the $\mathrm{CH}_{4}$ mixing ratio to be 2000 ppbv, which was the mean value in summer at Wangdu (Tan et al., 2017), for our Wangdu and Beijing sites. We acknowledge that the adoption of the summer $\mathrm{CH}_{4}$ concentrations for our winter studies may underestimate the $\mathrm{CH}_{4}$ level, but the effect on the $\mathrm{RO}_{x}$ budget is expected to be insignificant due to much smaller contribution of $\mathrm{CH}_{4}$ to $\mathrm{RO}_{x}$ than NMHCs and OVOCs in polluted environments. The photolysis frequencies of $\mathrm{ClNO}_{2}, \mathrm{O}_{3}$, and other species were simulated according to the solar zenith angle using the tropospheric ultraviolet and visible (TUV) radiation model and scaled by the observed $j \mathrm{NO}_{2}$ values. Numerical experiments were conducted by constraining (Case 1) and not constraining $\mathrm{ClNO}_{2}$ data (Case 2) at each site. The differences in the radical concentrations and $\mathrm{O}_{3}$ budgets between Cases 1 and 2 represented the effect of $\mathrm{ClNO}_{2}$. For example, the increase in $\mathrm{RO}_{x}(\%)$ due to $\mathrm{ClNO}_{2}$ was calculated by $\left(\mathrm{RO}_{x_{-}} \mathrm{W}\right.$ - $\left.\mathrm{RO}_{x_{-}} \mathrm{wo}\right) / \mathrm{RO}_{x_{-}}$wo, where $\mathrm{RO}_{x_{-}} \mathrm{w}$ represents the concentration of $\mathrm{RO}_{x}$ in Case 1 with $\mathrm{ClNO}_{2}$ constrained in the model, and $\mathrm{RO}_{x_{-}}$wo represents the concentration of $\mathrm{RO}_{x}$ in Case 2 without $\mathrm{ClNO}_{2}$ constrained.

\section{Results}

\subsection{Overall measurements, diurnal patterns, and comparison with other studies}

The time series of $\mathrm{N}_{2} \mathrm{O}_{5}$ and $\mathrm{ClNO}_{2}$ levels in the three campaigns are displayed in Fig. 1. Overall, elevated levels of $\mathrm{N}_{2} \mathrm{O}_{5}$ and $\mathrm{ClNO}_{2}$ were observed with different patterns at each site. The ground sites (Wangdu and Beijing) were characterized by high $\mathrm{NO}_{x}$ levels $(83.2 \pm 81.3 \mathrm{ppbv}$ and $35.6 \pm 27.3 \mathrm{ppbv}$, respectively) and low $\mathrm{O}_{3}$ levels $(8.5 \pm 8.8 \mathrm{ppbv}$ and $17.3 \pm 11.4 \mathrm{ppbv}$, respectively), whereas

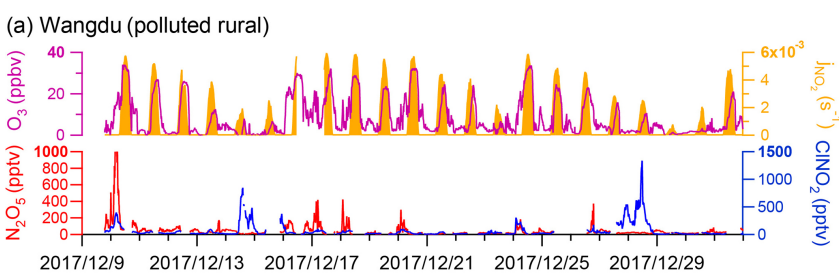

(b) Beijing (urban)

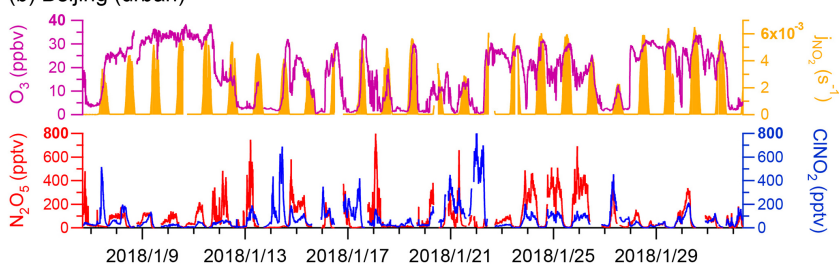

(c) Mt. Tai (polluted lower troposphere)

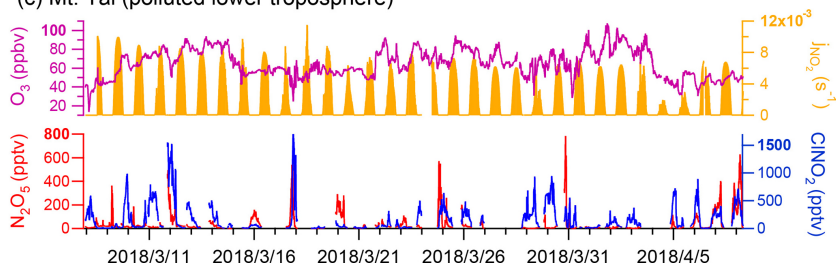

Figure 1. Overall observations of $\mathrm{N}_{2} \mathrm{O}_{5}, \mathrm{ClNO}_{2}$, and related species at the (a) Wangdu, (b) Beijing, and (c) Mt. Tai sites.

the mountain site, Mt. Tai, was marked by relatively lower $\mathrm{NO}_{x}$ levels $(2.4 \pm 2.0 \mathrm{ppbv})$ and higher $\mathrm{O}_{3}$ levels $(64.6 \pm 14.7 \mathrm{ppbv})$ (Fig. S8). The campaign-averaged mixing ratios of $\mathrm{ClNO}_{2}$ were similar at the ground sites $(71 \pm 132$ pptv and $76 \pm 103$ pptv in Wangdu and Beijing, respectively) and were significantly lower than that at Mt. Tai $(179 \pm 247$ pptv). The nocturnal ratio of $\mathrm{ClNO}_{2} / \mathrm{N}_{2} \mathrm{O}_{5}$ at each site displayed large day-to-day variability, which was positively dependent on the ambient RH (Fig. S9) and, to a lesser extent, positively correlated with $S_{\text {a }}$ (figure not shown).

The campaign-averaged diurnal patterns of the mixing ratios of $\mathrm{N}_{2} \mathrm{O}_{5}, \mathrm{ClNO}_{2}$, and related species are depicted in Fig. 2. $\mathrm{ClNO}_{2}$ levels typically exhibited a daily cycle, peaking at night and decreasing during the day. The diurnal pattern of $\mathrm{ClNO}_{2}$ at the Wangdu site in winter was an exception, with elevated concentrations (10th-90th percentiles) around midday (12:00-14:00 local time, LT), which resulted from a noontime peak in $\mathrm{ClNO}_{2}$ concentrations during a few days at Wangdu. The detailed observation results from each site are separately introduced as follows.

The nocturnal production of $\mathrm{ClNO}_{2}$ was insignificant in Wangdu despite the presence of abundant $\mathrm{Cl}^{-}$ $\left(3.3 \pm 3.2 \mu \mathrm{g} \mathrm{m}^{-3}\right.$ throughout the observation), which likely originated from the intensive residential coal combustion in the area (Peng et al., 2020). The Wangdu site experienced high mass concentrations of $\mathrm{PM}_{2.5}$ (a maximum of approximately $450 \mu \mathrm{g} \mathrm{m}^{-3}$ ) and very large mixing ratios of NO (a maximum of approximately $350 \mathrm{ppbv}$ ). The wind rose analysis showed that the high concentrations of NO originated 

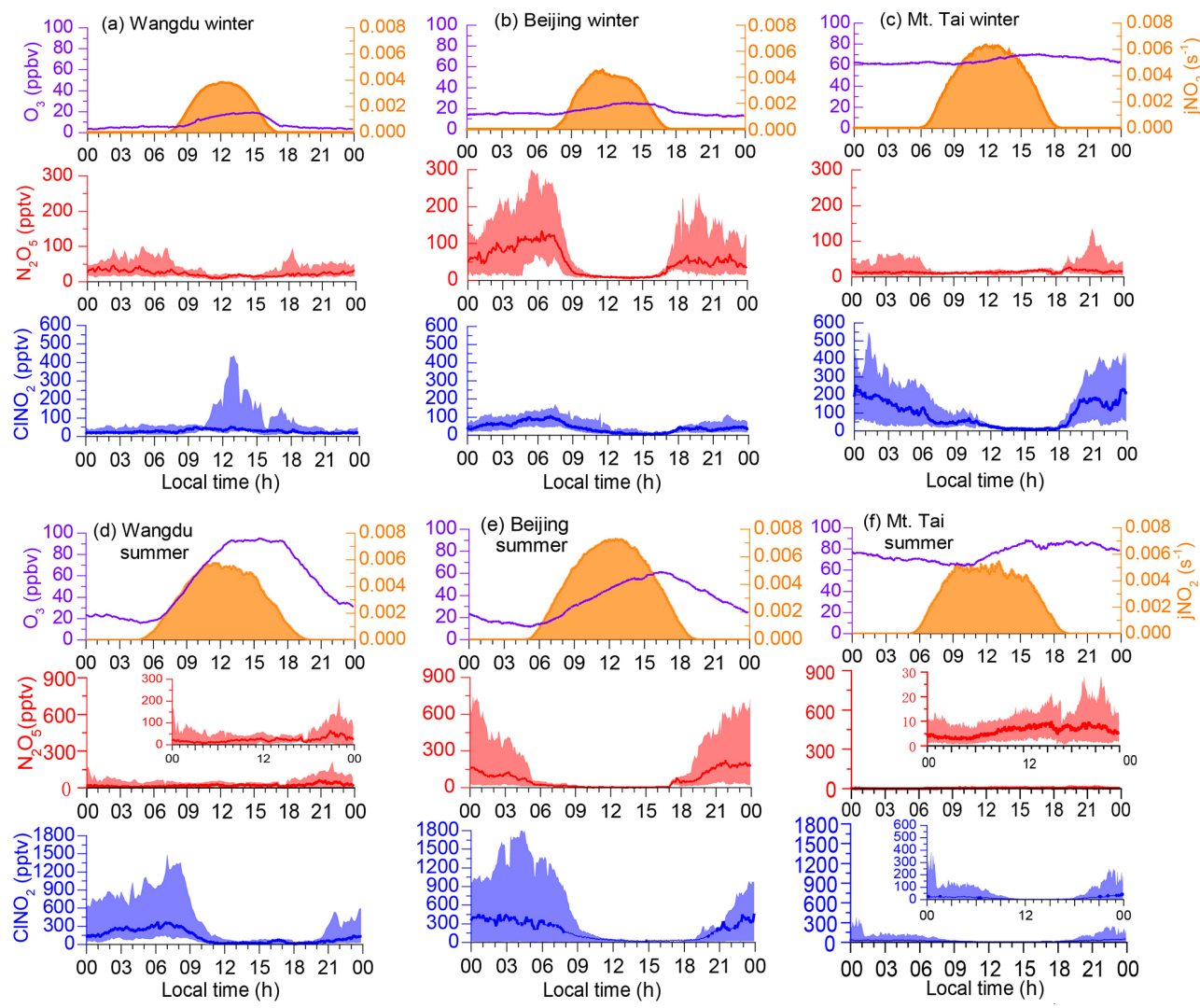

Figure 2. Diurnal average levels of $\mathrm{N}_{2} \mathrm{O}_{5}, \mathrm{ClNO}_{2}, \mathrm{O}_{3}$, and $j \mathrm{NO}_{2}$ observed at the Wangdu, Beijing, and Mt. Tai sites throughout the campaign in winter (this study) and previous summer field studies (Table 1). The shaded areas indicate the 10th and 90th percentiles.

from the west of the sampling site where two major roads were located. Numerous heavy-duty trucks on these roads were responsible for high $\mathrm{NO}$ concentrations. The presence of abundant $\mathrm{NO}$ inhibited $\mathrm{N}_{2} \mathrm{O}_{5}$ formation by consuming $\mathrm{O}_{3}$ and $\mathrm{NO}_{3}$ at the Wangdu site. When the ambient concentrations of NO substantially decreased, e.g., on 10 December, the $\mathrm{N}_{2} \mathrm{O}_{5}$ mixing ratios increased to $1 \mathrm{ppbv}$. The mixing ratios of $\mathrm{ClNO}_{2}$ were mostly low $(<200$ pptv) during the night. The relationship between nighttime levels of $\mathrm{ClNO}_{2}$ and grouped $\mathrm{NO}$ and $\mathrm{NO}_{x}$ concentrations is shown in Fig. 3. $\mathrm{ClNO}_{2}$ showed higher levels when the NO mixing ratios were below $10 \mathrm{ppbv}$ and $\mathrm{NO}_{x}$ mixing ratios ranged from 10-20 ppbv (Fig. 3a, d). However, significant daytime peaks in $\mathrm{ClNO}_{2}$ mixing ratios were observed on 14 and 28 December, reaching approximately 0.8 and $1.3 \mathrm{ppbv}$, respectively. The daytime peaks in $\mathrm{ClNO}_{2}$ concentrations at the three sites are discussed in detail in Sect. 3.3. For comparison, the ambient mixing ratios of $\mathrm{NO}$ in the summer campaign at Wangdu were much lower (mostly $0-10 \mathrm{ppbv}$ ), and $\mathrm{O}_{3}$ mixing ratios were much higher (i.e., exceeded 90 ppbv on most days), which favored the production of $\mathrm{N}_{2} \mathrm{O}_{5}$ and $\mathrm{ClNO}_{2}$ (Tham et al., 2016).

The winter Beijing observations showed that there was significant production of $\mathrm{N}_{2} \mathrm{O}_{5}$ but limited conversion of $\mathrm{N}_{2} \mathrm{O}_{5}$ to $\mathrm{ClNO}_{2}$ in dry conditions. The observation period in Beijing was divided into polluted days $\left(24 \mathrm{hPM}_{2.5}>75 \mu \mathrm{g} \mathrm{m}^{-3}\right.$; China's Grade II air quality standard for $\mathrm{PM}_{2.5}$ ) and clean days ( $24 \mathrm{~h} \mathrm{PM}_{2.5}<35 \mu \mathrm{g} \mathrm{m}^{-3}$; Grade I standard). The polluted periods were characterized by simultaneous high levels of $\mathrm{PM}_{2.5}$ and NO, e.g., on 19 January. The clean periods were marked by relatively high mixing ratios of $\mathrm{O}_{3}$ and low levels of $\mathrm{PM}_{2.5}$ and $\mathrm{NO}_{x}$, e.g., from 8 to 11 January. Both polluted and clean conditions were unfavorable for $\mathrm{ClNO}_{2}$ formation owing to the high concentrations of $\mathrm{NO}$ on the polluted days and the low concentrations of $\mathrm{NO}_{2}$ and aerosols on the clean days. Moreover, the RH observed in Beijing was typically below $40 \%$, which indicated relatively slow heterogeneous loss of $\mathrm{N}_{2} \mathrm{O}_{5}$ and slow $\mathrm{ClNO}_{2}$ formation. Consequently, $\mathrm{N}_{2} \mathrm{O}_{5}$ mixing ratios frequently accumulated to elevated levels, exceeding $0.4 \mathrm{ppbv}$ on 10 of the 26 observation nights, and the mixing ratio of $\mathrm{ClNO}_{2}$ was mostly below 0.4 ppbv. Nighttime levels of $\mathrm{ClNO}_{2}$ in winter Beijing were higher when $\mathrm{NO}$ mixing ratios ranged from $0-10$ ppbv and $\mathrm{NO}_{x}$ mixing ratios ranged 20-50 ppbv (Fig. 3b, d). The highest mixing ratios of $\mathrm{ClNO}_{2}$ were observed (up to approximately $0.8 \mathrm{ppbv}$ ) when the site occasionally intercepted air masses with a higher RH (approximately $75 \%$ ), e.g., on the night of 22 January. This result is similar to the previous observation in Beijing (Xia 

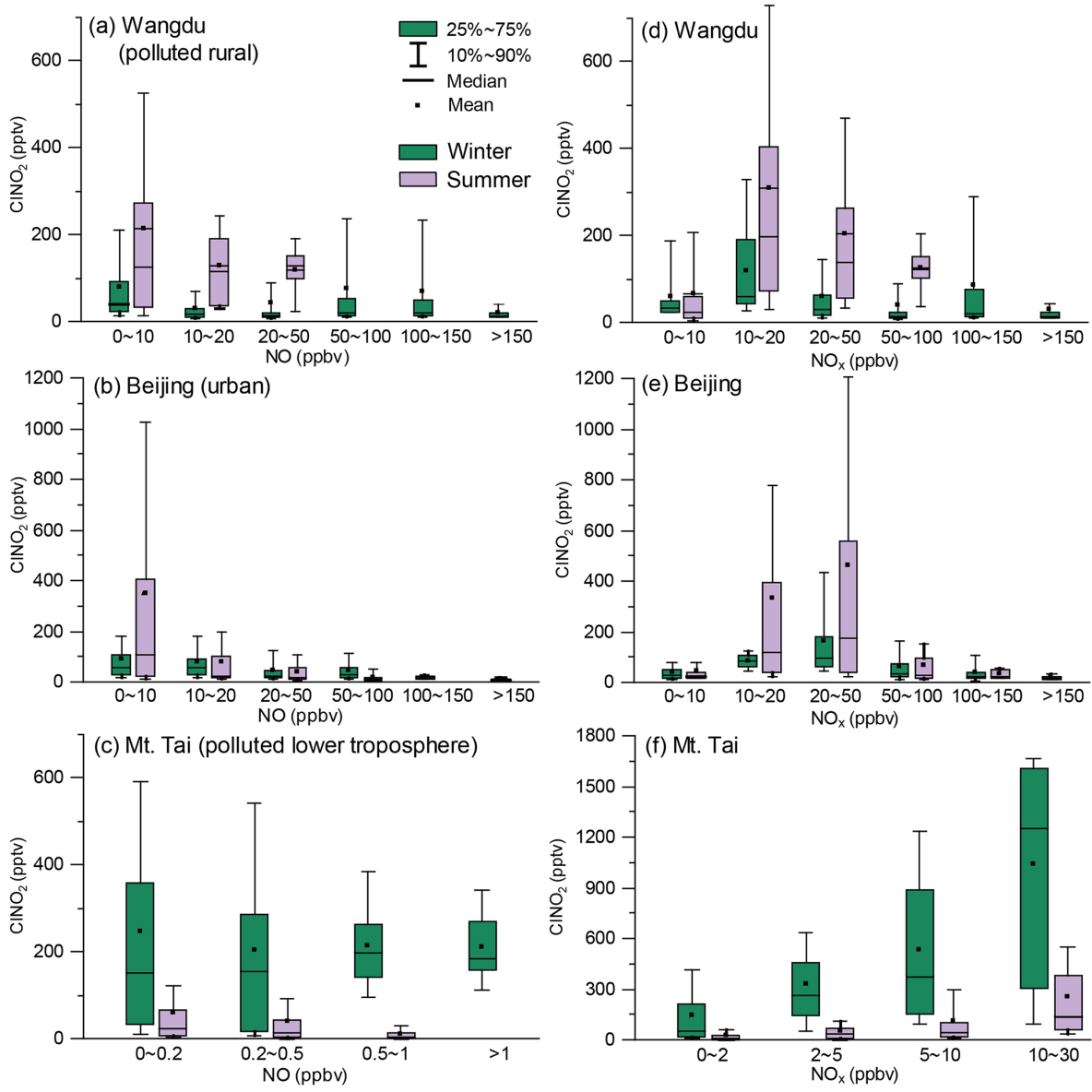

Figure 3. The relationship between nighttime levels of $\mathrm{ClNO}_{2}$ and grouped $\mathrm{NO}(\mathbf{a}, \mathbf{b}, \mathbf{c})$ and $\mathrm{NO}_{x}(\mathbf{d}, \mathbf{e}, \mathbf{f})$ mixing ratios in the winter $($ green color) and summer (purple color) campaigns. The difference in the scale of $\mathrm{ClNO}_{2}$ in (c) and (f) is caused by statistic factors, since only the 10th to 90th percentiles of $\mathrm{ClNO}_{2}$ data are shown here.

et al., 2019), in which the ratio of $\mathrm{ClNO}_{2}$ to $\mathrm{N}_{2} \mathrm{O}_{5}$ increased significantly from late spring with a low RH (10\%-30\%) to early summer with a higher RH $(20 \%-80 \%)$. The overall mixing ratios of $\mathrm{ClNO}_{2}$ in the present Beijing study in winter were also significantly lower than those reported in summer (maximum of 1.4 to $2.9 \mathrm{ppbv}$ ) in other studies (Le Breton et al., 2018; Zhou et al., 2018).

Elevated mixing ratios of $\mathrm{ClNO}_{2}$ (i.e., above $0.5 \mathrm{ppbv}$ ) were frequently recorded at the Mt. Tai station in winter. Nighttime levels of $\mathrm{ClNO}_{2}$ were slightly higher when NO levels were below 0.5 ppbv (Fig. 3c) and showed a positive correlation with $\mathrm{NO}_{x}$ levels (Fig. 3f). High concentrations of $\mathrm{PM}_{2.5}\left(34.5 \pm 27.3 \mu \mathrm{g} \mathrm{m}^{-3}\right)$ and high RH $(63.6 \pm 27.1 \%) \mathrm{fa}-$ vored the $\mathrm{ClNO}_{2}$ formation at Mt. Tai. The maximum level of $\mathrm{ClNO}_{2}$ (approximately $1.7 \mathrm{ppbv}$ ) was observed just before midnight on 18 March, which was slightly lower than the highest concentration observed at Mt. Tai in the summer of 2014 (Z. Wang et al., 2017). The elevated concentrations of $\mathrm{ClNO}_{2}$ observed in the previous summer study at Mt. Tai were due to emissions from distinct coal-fired power plants, whereas this winter study found that coal burning had less effect on concentrations of $\mathrm{ClNO}_{2}$. The campaign-averaged levels of $\mathrm{SO}_{2}$ and particulate $\mathrm{SO}_{4}^{2-}$ were $1.6 \pm 1.6 \mathrm{ppbv}$ and $3.6 \pm 2.9 \mu \mathrm{g} \mathrm{m}^{-3}$, respectively, during the winter observations, which were significantly lower than those observed in the summer campaigns $(2.9 \pm 3.7 \mathrm{ppbv}$ and $14.8 \pm 9.0 \mu \mathrm{g} \mathrm{m}^{-3}$, respectively). The decreases in $\mathrm{SO}_{2}$ and sulfate were attributed to strengthened emission control for coal-fired power generation during 2014-2018 and also less transport of emissions from the ground to the Mt. Tai site (1534 m a.s.1.) in late winter and early spring compared with that in summer.

We compared the observed winter concentrations of $\mathrm{ClNO}_{2}$ with those reported in previous studies in Asia, North America, and Europe (Fig. 4). The highest winter concentrations of $\mathrm{ClNO}_{2}$ to date were observed in southern China, with a maximum level of $4.7 \mathrm{ppbv}$ at a mountain top in Hong Kong in aged urban/industrial plumes from the Pearl River Delta (PRD) (Wang et al., 2016) and 8.3 ppbv during a severe pollution episode within the PRD (Yun et al., 2018). The high- 


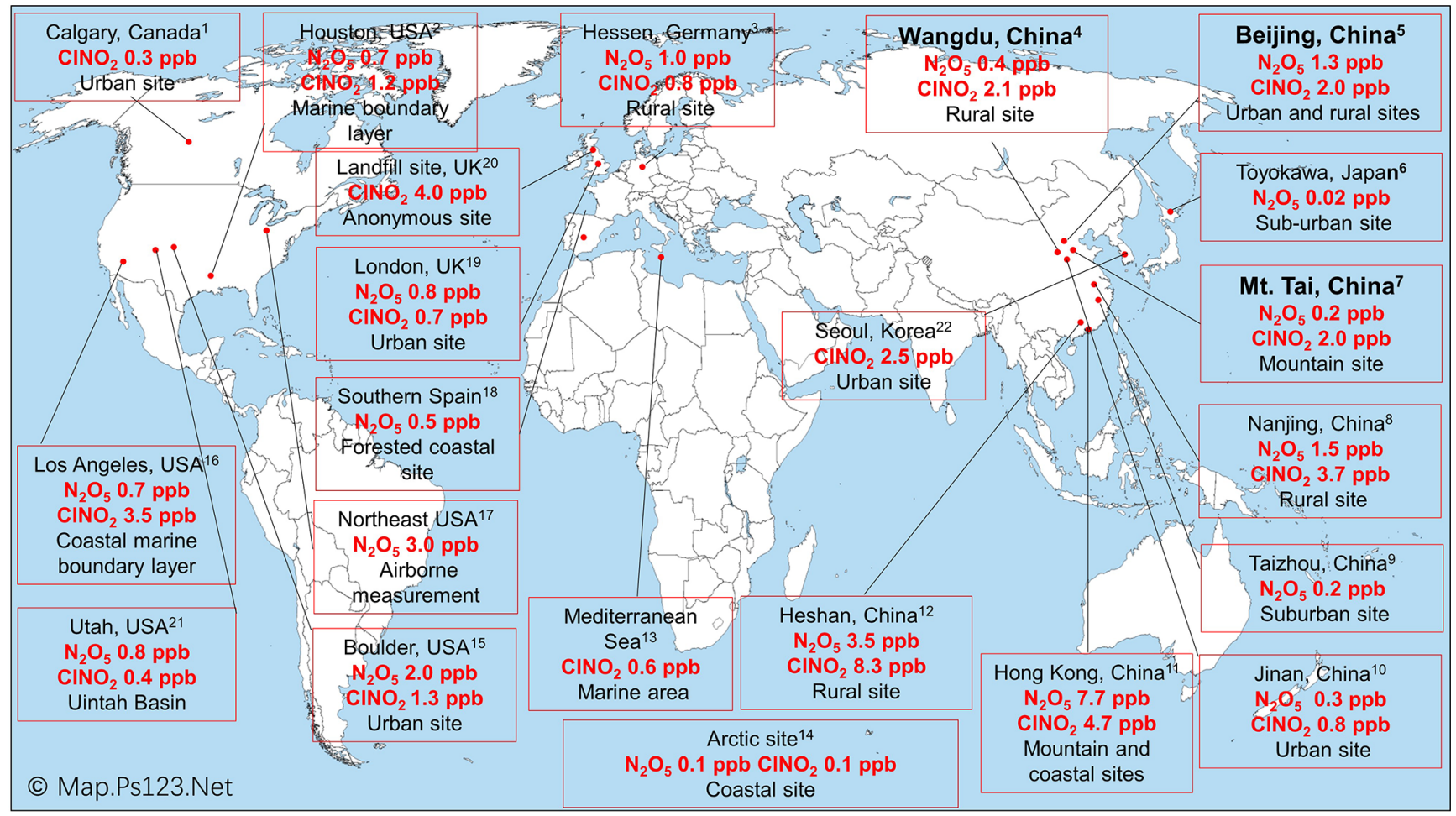

Figure 4. Previous observations of $\mathrm{ClNO}_{2}$ and $\mathrm{N}_{2} \mathrm{O}_{5}$ levels worldwide. Observation sites in this study are shown in bold. The $\mathrm{ClNO}$ and $\mathrm{N}_{2} \mathrm{O}_{5}$ levels shown are the highest that were measured at these sites. Footnotes associated with the locations refer to the references as follows. (1) Mielke et al. (2011), (2016); Osthoff et al. (2018). (2) Osthoff et al. (2008); Faxon et al. (2015). (3) Phillips et al. (2012). (4) Tham et al. (2016); Liu et al. (2017). (5) H. Wang et al. (2017); Le Breton et al. (2018); Wang et al. (2018); Zhou et al. (2018); Xia et al. (2019). (6) Nakayama et al. (2008). (7) Z. Wang et al. (2017). (8) Xia et al. (2020). (9) H. Wang et al. (2019). (10) X. Wang et al. (2017). (11) Wang et al. (2016); Yun et al. (2017); Yan et al. (2019). (12) Yun et al. (2018). (13) Eger et al. (2019). (14) Apodaca et al. (2008); McNamara et al. (2019). (15) Thornton et al. (2010); Riedel et al. (2013). (16) Riedel et al. (2012); Mielke et al. (2013). (17) Brown et al. (2006); Brown et al. (2007); Haskins et al. (2018). (18) Crowley et al. (2011). (19) Bannan et al. (2015); Sommariva et al. (2018). (20) Bannan et al. (2019). (21) Edwards et al. (2013); Wild et al. (2016); McDuffie et al. (2019). (22) Jeong et al. (2019).

concentration $\mathrm{ClNO}_{2}$ events in southern China were due to concurrent high levels of $\mathrm{PM}_{2.5}$ and $\mathrm{O}_{3}$ (e.g., $400 \mu \mathrm{g} \mathrm{m}^{-3}$ and 160 ppbv found by Yun et al., 2018), which contrast the high concentrations of $\mathrm{PM}_{2.5}$ and low concentrations of $\mathrm{O}_{3}$ over northern China during the cold winter. The winter mixing ratios of $\mathrm{ClNO}_{2}$ in the United States and Europe range from approximately $0.3 \mathrm{ppbv}$ in urban California (Mielke et al., 2016) and urban Manchester (Priestley et al., 2018), respectively, to $1.3 \mathrm{ppbv}$ in the outflow of coastal urban areas (Riedel et al., 2013; Haskins et al., 2019). In general, the winter concentrations of $\mathrm{ClNO}_{2}$ over northern China were comparable to or slightly higher than those observed in the United States and Europe.

\section{2 $\mathrm{NO}_{3}$ production and loss pathways}

To gain insight into the processes controlling the variability in concentrations of $\mathrm{ClNO}_{2}$, nocturnal $P\left(\mathrm{NO}_{3}\right)$ and $\mathrm{NO}_{3}$ loss pathways were compared using Eqs. (1-5) in Sect. 2.4. The average $P\left(\mathrm{NO}_{3}\right)$ was comparable at the three sites in winter, ranging from 0.15 to $0.25 \mathrm{ppbv} \mathrm{h}^{-1}$, and these rates were significantly lower than the respective summer values (Fig. 5a). The lower $P\left(\mathrm{NO}_{3}\right)$ in winter was caused by both lower $k_{1}$ and lower $\left[\mathrm{NO}_{2}\right] \times\left[\mathrm{O}_{3}\right]$ in winter (see Eq. 1). The lower $k_{1}$ in winter is caused by lower temperature in winter, while the lower $\left[\mathrm{NO}_{2}\right] \times\left[\mathrm{O}_{3}\right]$ in winter is mainly caused by less photochemical production of $\mathrm{O}_{3}$ and more $\mathrm{NO}$ that consumes the available $\mathrm{O}_{3}$ in winter (Table S5). Nighttime $\mathrm{NO}_{3}$ removal through $\mathrm{NO}_{3}$ and $\mathrm{N}_{2} \mathrm{O}_{5}$ was estimated by comparing $k\left(\mathrm{NO}_{3}\right) \times\left[\mathrm{NO}_{3}\right]\left(\right.$ Eqs. 2-3) and $k\left(\mathrm{~N}_{2} \mathrm{O}_{5}\right) \times\left[\mathrm{N}_{2} \mathrm{O}_{5}\right]$ (Eqs. 4-5). The average $\gamma\left(\mathrm{N}_{2} \mathrm{O}_{5}\right)$ values derived from each campaign (Table S6 and Fig. S10) were used in Eq. (4). The nighttime $\mathrm{NO}_{3}$ loss via $\mathrm{NO}$ titration and VOC oxidation was greater than the $\mathrm{N}_{2} \mathrm{O}_{5}$ heterogeneous loss in all the winter and summer campaigns (Fig. 5b). These were the campaign average results. In contrast, the $\mathrm{N}_{2} \mathrm{O}_{5}$ loss was greater than the $\mathrm{NO}_{3}$ loss in selected cases in summer at Mt. Tai (Wang et al., 2017c). To determine the nocturnal loss of $\mathrm{NO}_{3}$, we further compared the $\mathrm{N}_{2} \mathrm{O}_{5} / \mathrm{NO}_{3}$ ratio and $\gamma\left(\mathrm{N}_{2} \mathrm{O}_{5}\right)$ at the three sites. 


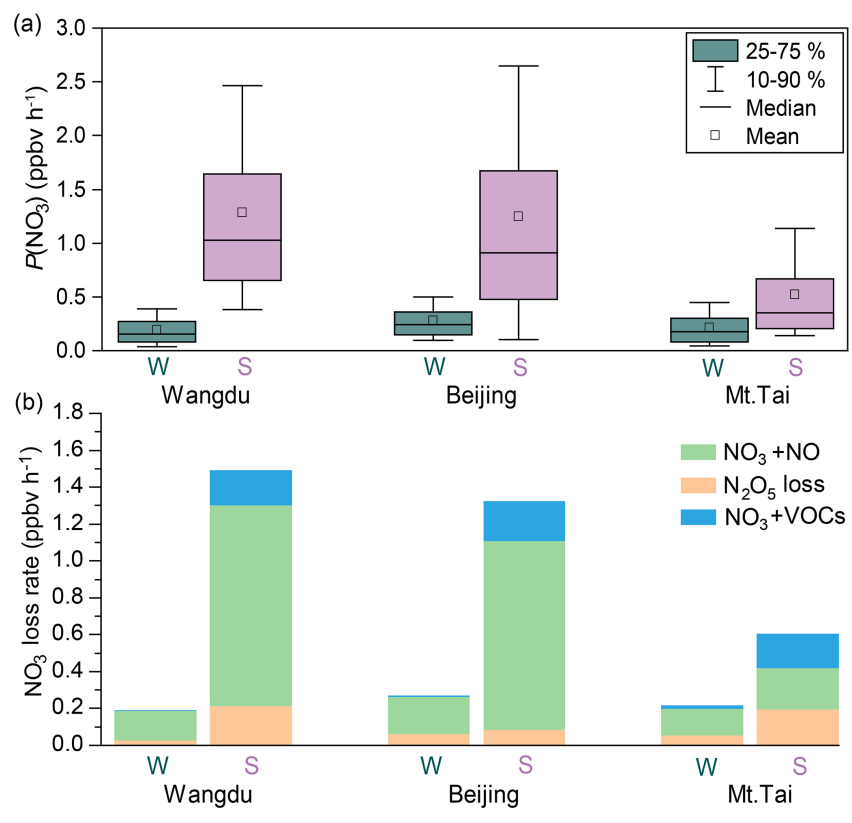

Figure 5. Comparison of $P\left(\mathrm{NO}_{3}\right)$ and loss pathways of $\mathrm{NO}_{3}$ during the winter and summer observations over the NCP. W and S are abbreviations for winter and summer, respectively.

The thermal decomposition of $\mathrm{N}_{2} \mathrm{O}_{5}$ was suppressed in winter and resulted in high ratios of $\mathrm{N}_{2} \mathrm{O}_{5} / \mathrm{NO}_{3}$ (Fig. 6a; up to approximately 1000), which favored $\mathrm{N}_{2} \mathrm{O}_{5}$ loss over $\mathrm{NO}_{3}$ loss. However, the $\gamma\left(\mathrm{N}_{2} \mathrm{O}_{5}\right)$ in winter was systematically lower than that in summer (Fig. 6b), which indicated slower $\mathrm{N}_{2} \mathrm{O}_{5}$ loss in winter. A previous field study in winter Beijing also reported small values of $\gamma\left(\mathrm{N}_{2} \mathrm{O}_{5}\right)$, ranging from $<0.001$ to 0.02 (Wang et al., 2020). This result differs from previous laboratory studies, which reported larger $\gamma\left(\mathrm{N}_{2} \mathrm{O}_{5}\right)$ on $\left(\mathrm{NH}_{4}\right)_{2} \mathrm{SO}_{4}$ aerosols at lower temperatures (Hallquist et al., 2003; Griffiths and Anthony Cox, 2009). It is possible that other factors, such as RH and aerosol composition (aside from $\left.\left(\mathrm{NH}_{4}\right)_{2} \mathrm{SO}_{4}\right)$, had a large influence on $\gamma\left(\mathrm{N}_{2} \mathrm{O}_{5}\right)$. The limited number (two to four) of $\gamma\left(\mathrm{N}_{2} \mathrm{O}_{5}\right)$ values obtained in each winter campaign (Table S6) may have also caused a bias in the estimation of the overall $\gamma\left(\mathrm{N}_{2} \mathrm{O}_{5}\right)$. The opposite effects - a higher $\mathrm{N}_{2} \mathrm{O}_{5} / \mathrm{NO}_{3}$ ratio and lower $\gamma\left(\mathrm{N}_{2} \mathrm{O}_{5}\right)$ in winter offset each other in Wangdu (Fig. 6b) but favored $\mathrm{N}_{2} \mathrm{O}_{5}$ loss in Beijing and $\mathrm{NO}_{3}$ loss at Mt. Tai compared with those in the respective summer campaigns. The higher concentrations of $\mathrm{ClNO}_{2}$ at Mt. Tai during the winter campaigns may be attributable to higher $\varphi\left(\mathrm{ClNO}_{2}\right)$ values in Mt. Tai (Fig. 6c).

\subsection{Daytime peaks in $\mathrm{ClNO}_{2}$ concentrations}

In the winter campaigns, high concentrations of $\mathrm{ClNO}_{2}$ were sustained after sunrise. Distinct peaks in $\mathrm{ClNO}_{2}$ concentrations were observed on 3-4 $\mathrm{d}$ in each campaign, as shown in Fig. 7 displaying one case at each site. Other daytime cases from the three sites are shown in Figs. S11-13. The valid- ity of the daytime peaks was checked by performing isotopic analysis of $\mathrm{ClNO}_{2}$, background detection, and on-site calibration. The signals of $\mathrm{I}^{35} \mathrm{ClNO}_{2}^{-}$and $\mathrm{I}^{37} \mathrm{ClNO}_{2}^{-}$were well correlated $\left(R^{2}>0.99\right)$ during daytime peaks in $\mathrm{ClNO}_{2}$ concentrations (Fig. S3a-c) and calibrations (Fig. S3d-f). The ratio of $\mathrm{I}^{37} \mathrm{ClNO}_{2}^{-}$to $\mathrm{I}^{35} \mathrm{ClNO}_{2}^{-}(0.32-0.35)$ was consistent with the natural isotopic ratio of ${ }^{37} \mathrm{Cl}$ to ${ }^{35} \mathrm{Cl}$. The background signals of $\mathrm{ClNO}_{2}$ were checked when its daytime peaks in concentrations were observed, and no increase in the background was found. We also checked the signal of primary ions $\left(\mathrm{IH}_{2} \mathrm{O}^{-}\right)$and found no abnormal changes when $\mathrm{ClNO}_{2}$ concentrations showed daytime peaks. These results confirmed that the daytime peaks in $\mathrm{ClNO}_{2}$ concentrations were real atmospheric phenomena.

The daytime $\mathrm{ClNO}_{2}$ episodes usually occurred from 10:00 to 11:00 LT at each site. The highest daytime mixing ratio of $\mathrm{ClNO}_{2}$ was $1.3 \mathrm{ppbv}$ ( $5 \mathrm{~min}$ average) observed at 11:30 on 28 December 2017 in Wangdu. In comparison, the daytime $\mathrm{ClNO}_{2}$ concentration observed in the previous summer study at Wangdu (Tham et al., 2016) reached a maximum in the early morning (08:00 LT) and declined to several parts per trillion by volume at 11:00. Attenuated solar radiation was observed during the days with daytime peaks in $\mathrm{ClNO}_{2}$ concentrations. For example, the daily maximum rates of $j \mathrm{NO}_{2}$ (1 min average) for the Wangdu case shown in Fig. 7a $\left(2.5 \times 10^{-3} \mathrm{~s}^{-1}\right)$ was significantly lower than the highest rate observed during this campaign $\left(6.0 \times 10^{-3} \mathrm{~s}^{-1}\right)$. The attenuated solar radiation reduced the photolysis of $\mathrm{ClNO}_{2}$, which allowed it to persist for a longer period during the day. The chemical data showed contrasting features during the daytime peaks in $\mathrm{ClNO}_{2}$ concentrations at the three sites. At Wangdu, $\mathrm{ClNO}_{2}$ concentrations showed a sharp peak while the concentrations of other pollutants decreased (Fig. 7a); in Beijing, the daytime peak in $\mathrm{ClNO}_{2}$ concentrations appeared with little simultaneous change in the $\mathrm{NO}_{3}^{-}, \mathrm{NO}_{x}$, and $\mathrm{O}_{3}$ levels after sunrise (Fig. S12a). In two cases, daytime peaks of $\mathrm{ClNO}_{2}$ concentrations at Mt. Tai (Figs. 7c and S13c) occurred together with significant increases in $\mathrm{NO}_{3}^{-}, \mathrm{NO}_{x}$, and $\mathrm{PM}_{2.5}$ levels, whereas $\mathrm{O}_{3}$ concentrations decreased after sunrise and resumed previous levels.

The daytime peaks in $\mathrm{ClNO}_{2}$ concentrations were likely caused by the transport of air masses to the respective sites. In situ production of $\mathrm{ClNO}_{2}$ was limited during the days on which significant daytime $\mathrm{ClNO}_{2}$ occurred, because the mixing ratios of $\mathrm{N}_{2} \mathrm{O}_{5}$ were near the detection limit of the instrument (several parts per trillion by volume). The photochemical lifetime of $\mathrm{ClNO}_{2}$ at 10:00 am LT was estimated to be $1-2 \mathrm{~h}$, based on the inverse of $j \mathrm{ClNO}_{2}$, which allowed the transport of $\mathrm{ClNO}_{2}$ produced elsewhere to the observation sites. As daytime peaks in $\mathrm{ClNO}_{2}$ concentrations appeared at both the ground and mountain sites, the high- $\mathrm{ClNO}_{2}$ region may exist in the residual layer above the nocturnal mixing layers. At sunrise, $\mathrm{ClNO}_{2}$-rich air masses may be transported downward to the ground sites (Wangdu and Beijing) and upward to the mountaintop site (Mt. Tai). The downward trans- 


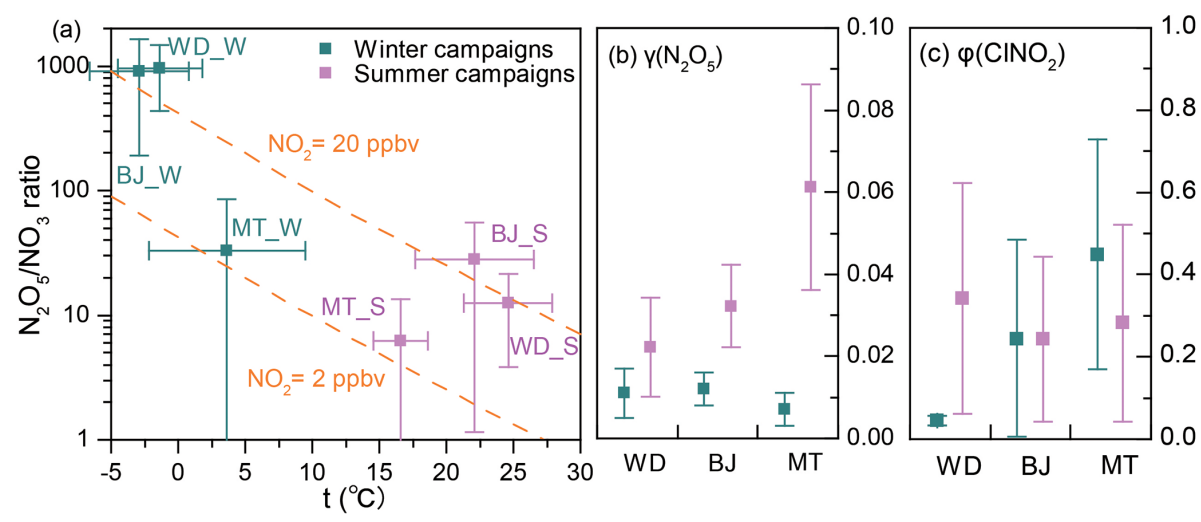

Figure 6. Comparison of the (a) $\mathrm{N}_{2} \mathrm{O}_{5} / \mathrm{NO}_{3}$ ratio, (b) $\gamma\left(\mathrm{N}_{2} \mathrm{O}_{5}\right)$, and (c) $\varphi\left(\mathrm{ClNO}_{2}\right)$ during the winter and summer campaigns. Square dots and error bars indicate the average values and standard deviations, respectively.

port of $\mathrm{ClNO}_{2}$ at Wangdu in summer has been illustrated by Tham et al. (2016), and the upward transport to the top of Mt. Tai has also been implicated by the increasing daytime concentrations of $\mathrm{O}_{3}$ and other pollutants (e.g., Gao et al., 2005; Zhou et al., 2009; Jiang et al., 2020). Measurements in the residual layers are needed to further investigate the transport of $\mathrm{ClNO}_{2}$ within the entire boundary layer.

\subsection{Impact of daytime $\mathrm{CINO}_{2}$ on atmospheric oxidation capacity}

We used the box model (Sect. 2.5) to show the impact of $\mathrm{ClNO}_{2}$ on photochemical oxidation at the three sites (Fig. 7a-c). In campaign-averaged conditions, the impact of $\mathrm{ClNO}_{2}$ was minor, owing to the low daytime concentrations of $\mathrm{ClNO}_{2}$. The daytime-averaged $P(\mathrm{Cl})$ (06:0018:00 LT) from $\mathrm{ClNO}_{2}$ photolysis was in the range of $0.03-$ $0.06 \mathrm{ppbvh}^{-1}$, with the peak values of $0.07-0.12 \mathrm{ppbvh}^{-1}$, and the photolysis of $\mathrm{ClNO}_{2}$ enhanced the daytime $\mathrm{RO}_{x}$ concentrations by $1.3 \%-3.8 \%$ and net $\mathrm{O}_{3}$ production by $1.3 \%-$ $6.2 \%$ at the three sites (figures not shown). Such impacts were lower than those during summer at Wangdu (Tham et al., 2016).

However, the impact of $\mathrm{ClNO}_{2}$ increased considerably in the cases of daytime-peak concentrations, as shown in Fig. 8. The daytime-averaged $P(\mathrm{Cl})$ values from $\mathrm{ClNO}_{2}$ photolysis were $0.15 \pm 0.13$ (maximum of 0.46 ), $0.11 \pm 0.09$ (maximum of 0.32 ), and $0.19 \pm 0.20$ (maximum of 0.74 ) $\mathrm{ppbv} \mathrm{h}^{-1}$ at Wangdu, Beijing, and Mt. Tai, respectively (Fig. 8a-c). The winter $P(\mathrm{Cl})$ peak in Wangdu (Fig. 8a, $0.46 \mathrm{ppbv} \mathrm{h}^{-1}$ ) was twice the summer average value $\left(0.24 \mathrm{ppbv} \mathrm{h}^{-1}\right)$ (Tham et al., 2016). The $P(\mathrm{Cl})$ during the daytime peaks of $\mathrm{ClNO}_{2}$ in this study is significantly higher than that in Riedel et al. (2012) (maximum $\sim 0.08 \mathrm{ppbv} \mathrm{h}^{-1}$ ) but slightly lower than that in Haskins et al. (2019) (maximum $\sim 1.3 \mathrm{ppbv} \mathrm{h}^{-1}$ ). $P(\mathrm{Cl})$ from other sources (e.g., the $\mathrm{HCl}+\mathrm{OH}$ reaction) was minor $(8.8 \%-14.5 \%)$ during these cases. The relative importance of $\mathrm{ClNO}_{2}$ in primary radical production varied among these sites. $\mathrm{ClNO}_{2}$ had a minor contribution in Beijing but became increasingly important in Wangdu and Mt. Tai (Fig. 8b, c). HONO photolysis was the most important source of $\mathrm{OH}$ at the two ground sites, whereas $\mathrm{O}_{3}$ was also important at Mt. Tai.

The liberated $\mathrm{Cl}$ (mostly from $\mathrm{ClNO}_{2}$ photolysis) accounted for $28.5 \%-57.7 \%$ of the daytime (06:00-18:00 LT) oxidation of alkanes, $6.1 \%-13.7 \%$ of that of alkenes, $5.3 \%-$ $14.2 \%$ of that of aromatics, and $4.6 \%-6.0 \%$ of that of aldehydes in the cases of high levels of daytime $\mathrm{ClNO}_{2}$. The $\mathrm{Cl}$ + VOC reactions enhanced the production of $\mathrm{OH}, \mathrm{HO}_{2}$, and $\mathrm{RO}_{2}$ by up to $15 \%-22 \%, 24 \%-31 \%$, and $36 \%-52 \%$, respectively (Fig. 8d-f). The photolysis of $\mathrm{ClNO}_{2}$ increased the daytime net $\mathrm{O}_{3}$ production by $5.4 \mathrm{ppbv}(18 \%), 2.8 \mathrm{ppbv}$ $(17 \%)$, and $2.6 \mathrm{ppbv}(13 \%)$ at Wangdu, Beijing, and Mt. Tai, respectively (Fig. 8g-i). These results indicate the considerable impact of daytime $\mathrm{ClNO}_{2}$ on the atmospheric oxidative capacity and production of secondary pollutants.

The impact of $\mathrm{Cl}$ in the NCP is likely larger than the result shown above. Our model calculations considered photolysis of $\mathrm{ClNO}_{2}$ (and $\mathrm{HCl}+\mathrm{OH}$ ) as the source of $\mathrm{Cl}$, but not other photolabile $\mathrm{Cl}$-containing gases. However, in the Wangdu field campaign, we frequently observed elevated daytime concentrations of bromine chloride $(\mathrm{BrCl})$ and molecular chlorine $\left(\mathrm{Cl}_{2}\right)$, which dominated the $\mathrm{Cl}$ production (Peng et al., 2020). In addition, our $\mathrm{ClNO}_{2}$ measurements were conducted at polluted ground-level sites and at a high mountain site ( $1534 \mathrm{~m}$ a.s.l.), which are not in the nocturnal residual layer where strong $\mathrm{ClNO}_{2}$ production is expected to occur (Zhang et al., 2017). It is thus highly desirable to measure $\mathrm{ClNO}_{2}$ in the residual layer in future studies to comprehensively assess the role of $\mathrm{ClNO}_{2}$ in the lower part of the atmosphere. 

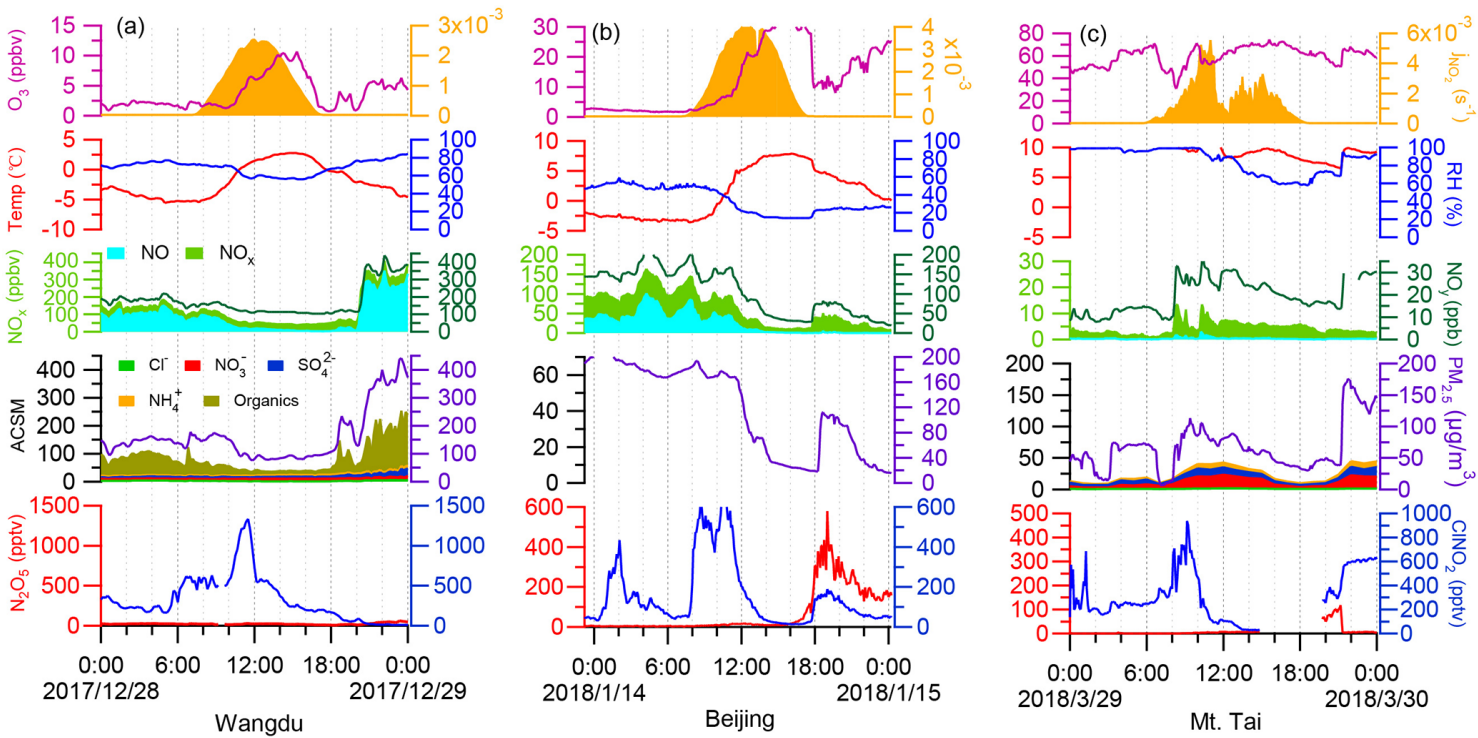

Figure 7. Examples of daytime peaks of $\mathrm{ClNO}_{2}$ levels observed at (a) Wangdu, (b) Beijing, and (c) Mt. Tai in the winter campaigns. These examples show the highest levels of daytime $\mathrm{ClNO}_{2}$ at each site. The ionic composition of aerosols was not available on $14 \mathrm{January} 2018$, owing to an instrument problem.
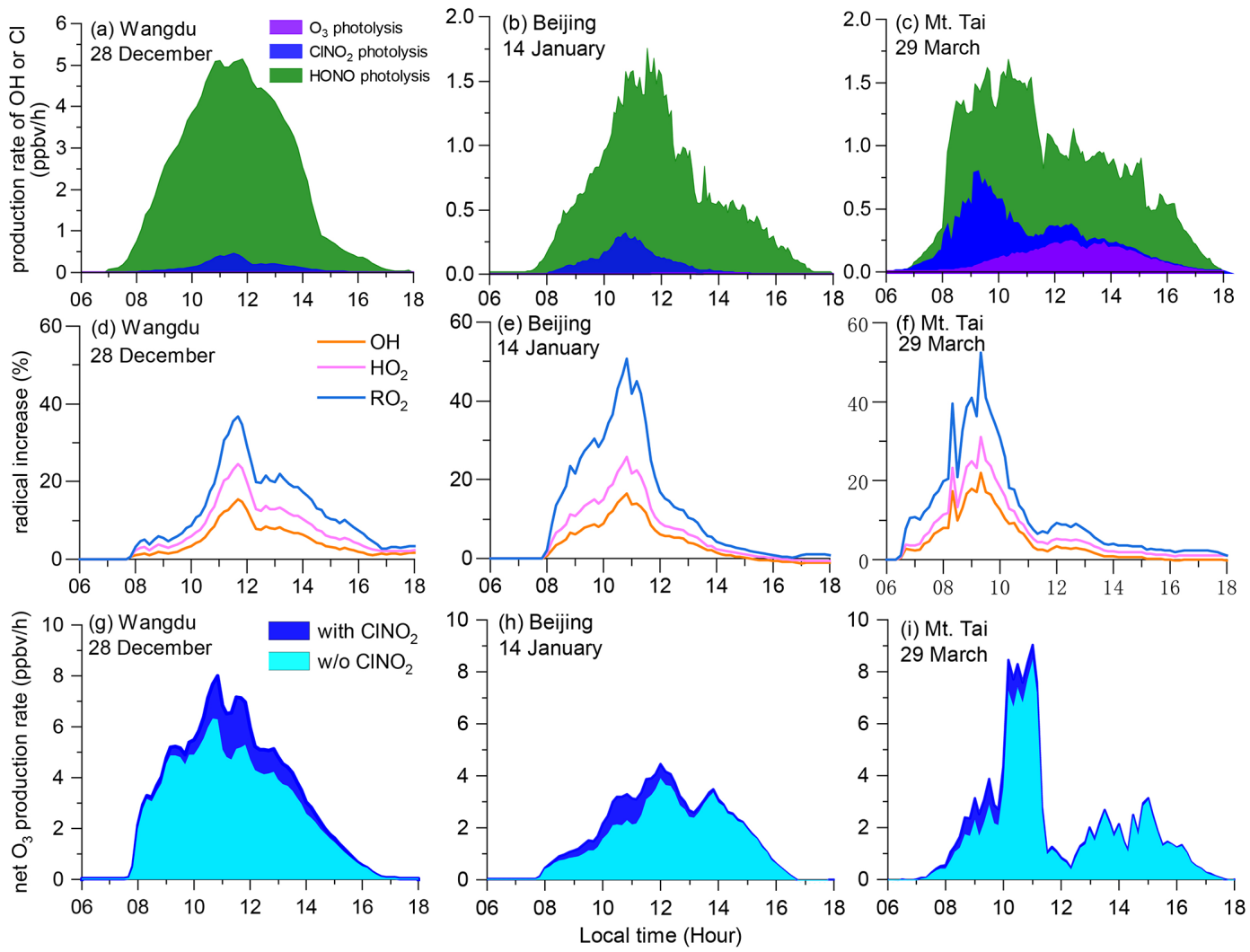

Figure 8. The impact of $\mathrm{ClNO}_{2}$ photolysis on atmospheric oxidation during daytime-ClNO $\mathrm{C}_{2}$ episodes: (a) primary radical production from the photolysis of $\mathrm{O}_{3}, \mathrm{ClNO}_{2}$, and $\mathrm{HONO}$; (b) percentage increase in $\mathrm{OH}, \mathrm{HO}_{2}$, and $\mathrm{RO}_{2}$ due to $\mathrm{ClNO}_{2}$ photolysis (Sect. 2.5); and (c) enhancement of net $\mathrm{O}_{3}$ production rates due to $\mathrm{ClNO}_{2}$ photolysis. 


\section{Summary and conclusions}

Observations of $\mathrm{ClNO}_{2}$ and related species were conducted at urban, polluted rural, and polluted lower tropospheric sites in the winter of 2017-2018 in the NCP, which suffers from severe winter haze pollution. The winter measurements showed lower concentrations of $\mathrm{ClNO}_{2}$ compared with those in previous summer observations. The campaign-averaged $\mathrm{NO}_{3}$ loss via reaction with $\mathrm{NO}$ at night dominated over the $\mathrm{N}_{2} \mathrm{O}_{5}$ loss at all the sites due to high NO concentrations, and in situ $\mathrm{ClNO}_{2}$ formation was generally insignificant. However, high levels of daytime $\mathrm{ClNO}_{2}$ (exceeding $1 \mathrm{ppbv}$ ) were observed at the three sites. We suggest that $\mathrm{ClNO}_{2}$ was efficiently produced in the nocturnal residual layer and was transported to ground-level and high-elevation sites. The daytime concentrations of $\mathrm{ClNO}_{2}$ had great effects on the production of $\mathrm{Cl}, \mathrm{RO}_{x}$, and $\mathrm{O}_{3}$. Vertical measurements of the concentrations of $\mathrm{ClNO}_{2}$ and related compounds are needed to better understand the distribution and impact of these species in the lower troposphere. Compared to the previous studies in the clean troposphere or in more aged air masses, our results provide new insights into $\mathrm{ClNO}_{2}$ formation in the region affected by fresh and intense anthropogenic emissions.

Data availability. The datasets described in this study are available by contacting the corresponding author (cetwang@polyu.edu.hk).

Supplement. The supplement related to this article is available online at: https://doi.org/10.5194/acp-21-15985-2021-supplement.

Author contributions. TW designed this study. JC, YM, LX, JG, and HL provided field measurement sites. MX, XP, and WW conducted the CIMS measurements. CY, ZW, YJT, HC, CZ, PL, and $\mathrm{XW}$ provided supporting data. XP and WW performed the box model simulation. MX analyzed and virtualized the research data. MX and TW wrote the manuscript with discussions and comments from all co-authors.

Competing interests. The authors declare that they have no conflict of interest.

Disclaimer. Publisher's note: Copernicus Publications remains neutral with regard to jurisdictional claims in published maps and institutional affiliations.

Acknowledgements. The authors are grateful to Yujie Zhang, Fang $\mathrm{Bi}$, Zhenhai $\mathrm{Wu}$, and $\mathrm{Xi}$ Cheng for providing supporting data in Beijing. The authors acknowledge helpful discussions and opinions from Peng Wang and Xiao Fu and logistics support from Liwei
Guan in Wangdu, and they thank the meteorological observatory at Mt. Tai for providing experiment platforms.

Financial support. This work was funded by National Natural Science Foundation of China (grant nos. 91544213, 91844301, and 41922051), the Hong Kong Research Grants Council (grant nos. T24-504/17-N and A-PolyU502/16), and the National Key Research and Development Program of China (grant no. 2016YFC0200500).

Review statement. This paper was edited by Gabriele Stiller and reviewed by Jessica Haskins and one anonymous referee.

\section{References}

Achtert, P., Birmili, W., Nowak, A., Wehner, B., Wiedensohler, A., Takegawa, N., Kondo, Y., Miyazaki, Y., Hu, M., and Zhu, T.: Hygroscopic growth of tropospheric particle number size distributions over the North China Plain, J. Geophys. Res.-Atmos., 114, D00G07, https://doi.org/10.1029/2008JD010921, 2009.

An, Z., Huang, R.-J., Zhang, R., Tie, X., Li, G., Cao, J., Zhou, W., Shi, Z., Han, Y., Gu, Z., and Ji, Y.: Severe haze in northern China: A synergy of anthropogenic emissions and atmospheric processes, P. Natl. Acad. Sci. USA, 116, 8657-8666, 2019.

Apodaca, R. L., Huff, D. M., and Simpson, W. R.: The role of ice in $\mathrm{N}_{2} \mathrm{O}_{5}$ heterogeneous hydrolysis at high latitudes, Atmos. Chem. Phys., 8, 7451-7463, https://doi.org/10.5194/acp-8-7451-2008, 2008.

Atkinson, R. and Arey, J.: Atmospheric degradation of volatile organic compounds, Chem. Rev., 103, 4605-4638, 2003.

Atkinson, R. and Lloyd, A. C.: Evaluation of kinetic and mechanistic data for modeling of photochemical smog, J. Phys. Chem, Ref. Data, 13, 315-444, 1984.

Bannan, T. J., Booth, A. M., Bacak, A., Muller, J. B. A., Leather, K. E., Le Breton, M., Jones, B., Young, D., Coe, H., Allan, J., Visser, S., Slowik, J. G., Furger, M., Prévôt, A. S. H., Lee, J., Dunmore, R. E., Hopkins, J. R., Hamilton, J. F., Lewis, A. C., Whalley, L. K., Sharp, T., Stone, D., Heard, D. E., Fleming, Z. L., Leigh, R., Shallcross, D. E., and Percival, C. J.: The first UK measurements of nitryl chloride using a chemical ionization mass spectrometer in central London in the summer of 2012, and an investigation of the role of $\mathrm{Cl}$ atom oxidation, J. Geophys. Res.-Atmos., 120, 5638-5657, 2015.

Bannan, T. J., Khan, M. A. H., Le Breton, M., Priestley, M., Worrall, S. D., Bacak, A., Marsden, N. A., Lowe, D., Pitt, J., and Allen, G.: A large source of atomic chlorine from $\mathrm{ClNO}_{2}$ photolysis at a UK landfill site, Geophys. Res. Lett., 46, 8508-8516, 2019.

Behnke, W., George, C., Scheer, V., and Zetzsch, C.: Production and decay of $\mathrm{ClNO}_{2}$ from the reaction of gaseous $\mathrm{N}_{2} \mathrm{O}_{5}$ with $\mathrm{NaCl}$ solution: Bulk and aerosol experiments, J. Geophys. Res.Atmos., 102, 3795-3804, 1997.

Bertram, T. H. and Thornton, J. A.: Toward a general parameterization of $\mathrm{N}_{2} \mathrm{O}_{5}$ reactivity on aqueous particles: the competing effects of particle liquid water, nitrate and chloride, Atmos. Chem. Phys., 9, 8351-8363, https://doi.org/10.5194/acp-9-8351-2009, 2009. 
Bertram, T. H., Thornton, J. A., Riedel, T. P., Middlebrook, A. M., Bahreini, R., Bates, T. S., Quinn, P. K., and Coffman, D. J.: Direct observations of $\mathrm{N}_{2} \mathrm{O}_{5}$ reactivity on ambient aerosol particles, Geophys. Res. Lett., 36, L19803, https://doi.org/10.1029/2009GL040248, 2009.

Brown, S., Ryerson, T., Wollny, A., Brock, C., Peltier, R., Sullivan, A., Weber, R., Dube, W., Trainer, M., and Meagher, J.: Variability in nocturnal nitrogen oxide processing and its role in regional air quality, Science, 311, 67-70, 2006.

Brown, S. S., Stark, H., Ryerson, T. B., Williams, E. J., Nicks, D. K., Trainer, M., Fehsenfeld, F. C., and Ravishankara, A.: Nitrogen oxides in the nocturnal boundary layer: Simultaneous in situ measurements of $\mathrm{NO}_{3}, \mathrm{~N}_{2} \mathrm{O}_{5}, \mathrm{NO}_{2}, \mathrm{NO}$, and $\mathrm{O}_{3}$, J. Geophys. Res.-Atmos., 108, 4299, https://doi.org/10.1029/2002JD002917, 2003.

Brown, S. S., Dubé, W. P., Osthoff, H. D., Stutz, J., Ryerson, T. B., Wollny, A. G., Brock, C. A., Warneke, C., De Gouw, J. A., and Atlas, E.: Vertical profiles in $\mathrm{NO}_{3}$ and $\mathrm{N}_{2} \mathrm{O}_{5}$ measured from an aircraft: Results from the NOAA P-3 and surface platforms during the New England Air Quality Study 2004, J. Geophys. Res.Atmos., 112, D22304, https://doi.org/10.1029/2007JD008883, 2007.

Burkholder, J., Sander, S., Abbatt, J., Barker, J., Huie, R., Kolb, C., Kurylo, M., Orkin, V., Wilmouth, D., and Wine, P.: Chemical kinetics and photochemical data for use in atmospheric studies: evaluation number 18, Pasadena, CA, Jet Propulsion Laboratory, National Aeronautics and Space, 2015.

Chang, W. L., Bhave, P. V., Brown, S. S., Riemer, N., Stutz, J., and Dabdub, D.: Heterogeneous atmospheric chemistry, ambient measurements, and model calculations of $\mathrm{N}_{2} \mathrm{O}_{5}$ : A review, Aerosol Sci. Tech., 45, 665-695, 2011.

Crowley, J. N., Thieser, J., Tang, M. J., Schuster, G., Bozem, H., Beygi, Z. H., Fischer, H., Diesch, J.-M., Drewnick, F., Borrmann, S., Song, W., Yassaa, N., Williams, J., Pöhler, D., Platt, U., and Lelieveld, J.: Variable lifetimes and loss mechanisms for $\mathrm{NO}_{3}$ and $\mathrm{N}_{2} \mathrm{O}_{5}$ during the DOMINO campaign: contrasts between marine, urban and continental air, Atmos. Chem. Phys., 11, 10853-10870, https://doi.org/10.5194/acp-11-108532011, 2011.

DeMore, W. B., Sander, S. P., Golden, D. M., Hampson, R. F., Kurylo, M. J., Howard, C. J., Ravishankara, A. R., Kolb, C. E., and Molina, M. J.: Chemical Kinetics and Photochemistry data for use in Stratospheric Modeling. Evaluation number 12, JPL Publication 97-4, JPL, Pasadena, CA, 1997.

Edwards, P. M., Young, C. J., Aikin, K., deGouw, J., Dubé, W. P., Geiger, F., Gilman, J., Helmig, D., Holloway, J. S., Kercher, J., Lerner, B., Martin, R., McLaren, R., Parrish, D. D., Peischl, J., Roberts, J. M., Ryerson, T. B., Thornton, J., Warneke, C., Williams, E. J., and Brown, S. S.: Ozone photochemistry in an oil and natural gas extraction region during winter: simulations of a snow-free season in the Uintah Basin, Utah, Atmos. Chem. Phys., 13, 8955-8971, https://doi.org/10.5194/acp13-8955-2013, 2013.

Eger, P. G., Friedrich, N., Schuladen, J., Shenolikar, J., Fischer, H., Tadic, I., Harder, H., Martinez, M., Rohloff, R., Tauer, S., Drewnick, F., Fachinger, F., Brooks, J., Darbyshire, E., Sciare, J., Pikridas, M., Lelieveld, J., and Crowley, J. N.: Shipborne measurements of $\mathrm{ClNO}_{2}$ in the Mediterranean Sea and around the Arabian Peninsula during summer, Atmos. Chem.
Phys., 19, 12121-12140, https://doi.org/10.5194/acp-19-121212019, 2019.

Faxon, C., Bean, J., and Ruiz, L.: Inland Concentrations of $\mathrm{Cl}_{2}$ and $\mathrm{ClNO}_{2}$ in Southeast Texas suggest chlorine chemistry significantly contributes to atmospheric reactivity, Atmosphere, 6, 1487-1506, 2015.

Finlayson-Pitts, B., Ezell, M., and Pitts, J.: Formation of chemically active chlorine compounds by reactions of atmospheric $\mathrm{NaCl}$ particles with gaseous $\mathrm{N}_{2} \mathrm{O}_{5}$ and $\mathrm{ClONO}_{2}$, Nature, 337, 241244, 1989.

Fu, X., Wang, T., Wang, S., Zhang, L., Cai, S., Xing, J., and Hao, J.: Anthropogenic emissions of hydrogen chloride and fine particulate chloride in China, Environ. Sci. Technol., 52, 1644-1654, 2018.

Fu, X., Wang, T., Gao, J., Wang, P., Liu, Y., Wang, S., Zhao, B., and Xue, L.: Persistent Heavy Winter Nitrate Pollution Driven by Increased Photochemical Oxidants in Northern China, Environ. Sci. Technol., 54, 3881-3889, 2020.

Gao, J., Wang, T., Ding, A., and Liu, C.: Observational study of ozone and carbon monoxide at the summit of mount Tai (1534 masl) in central-eastern China, Atmos. Environ., 39, 4779-4791, 2005.

Griffiths, P. T. and Anthony Cox, R.: Temperature dependence of heterogeneous uptake of $\mathrm{N}_{2} \mathrm{O}_{5}$ by ammonium sulfate aerosol, Atmos. Sci. Lett., 10, 159-163, 2009.

Gu, Y., Li, Q., Wei, D., Gao, L., Tan, L., Su, G., Liu, G., Liu, W., Li, C., and Wang, Q.: Emission characteristics of 99 NMVOCs in different seasonal days and the relationship with air quality parameters in Beijing, China, Ecotox. Environ. Safe., 169, 797806, 2019.

Hallquist, M., Stewart, D. J., Stephenson, S. K., and Cox, R. A.: Hydrolysis of $\mathrm{N}_{2} \mathrm{O}_{5}$ on sub-micron sulfate aerosols, Phys. Chem. Chem. Phys., 5, 3453-3463, 2003.

Haskins, J., Lopez-Hilfiker, F., Lee, B., Shah, V., Wolfe, G., DiGangi, J., Fibiger, D., McDuffie, E., Veres, P., and Schroder, J.: Anthropogenic control over wintertime oxidation of atmospheric pollutants, Geophys. Res. Lett., 46, 14826-14835, 2019.

Haskins, J. D., Jaeglé, L., Shah, V., Lee, B. H., Lopez-Hilfiker, F. D., Campuzano-Jost, P., Schroder, J. C., Day, D. A., Guo, H., and Sullivan, A. P.: Wintertime Gas-Particle Partitioning and Speciation of Inorganic Chlorine in the Lower Troposphere Over the Northeast United States and Coastal Ocean, J. Geophys. Res.Atmos., 123, 12897-812916, 2018.

Jenkin, M. E., Young, J. C., and Rickard, A. R.: The MCM v3.3.1 degradation scheme for isoprene, Atmos. Chem. Phys., 15, 11433-11459, https://doi.org/10.5194/acp-15-11433-2015, 2015.

Jeong, D., Seco, R., Gu, D., Lee, Y., Nault, B. A., Knote, C. J., Mcgee, T., Sullivan, J. T., Jimenez, J. L., Campuzano-Jost, P., Blake, D. R., Sanchez, D., Guenther, A. B., Tanner, D., Huey, L. G., Long, R., Anderson, B. E., Hall, S. R., Ullmann, K., Shin, H., Herndon, S. C., Lee, Y., Kim, D., Ahn, J., and Kim, S.: Integration of airborne and ground observations of nitryl chloride in the Seoul metropolitan area and the implications on regional oxidation capacity during KORUS-AQ 2016, Atmos. Chem. Phys., 19, 12779-12795, https://doi.org/10.5194/acp-1912779-2019, 2019.

Jiang, Y., Xue, L., Gu, R., Jia, M., Zhang, Y., Wen, L., Zheng, P., Chen, T., Li, H., Shan, Y., Zhao, Y., Guo, Z., Bi, Y., Liu, H., Ding, 
A., Zhang, Q., and Wang, W.: Sources of nitrous acid (HONO) in the upper boundary layer and lower free troposphere of the North China Plain: insights from the Mount Tai Observatory, Atmos. Chem. Phys., 20, 12115-12131, https://doi.org/10.5194/acp-2012115-2020, 2020.

Kenagy, H. S., Sparks, T. L., Ebben, C. J., Wooldrige, P. J., LopezHilfiker, F. D., Lee, B. H., Thornton, J. A., McDuffie, E. E., Fibiger, D. L., and Brown, S. S.: $\mathrm{NO}_{x}$ Lifetime and $\mathrm{NO}_{y}$ Partitioning During WINTER, J. Geophys. Res.-Atmos., 123, D028736 https://doi.org/10.1029/2018JD028736, 2018.

Le Breton, M., Hallquist, ̊. M., Pathak, R. K., Simpson, D., Wang, Y., Johansson, J., Zheng, J., Yang, Y., Shang, D., Wang, H., Liu, Q., Chan, C., Wang, T., Bannan, T. J., Priestley, M., Percival, C. J., Shallcross, D. E., Lu, K., Guo, S., Hu, M., and Hallquist, M.: Chlorine oxidation of VOCs at a semi-rural site in Beijing: significant chlorine liberation from $\mathrm{ClNO}_{2}$ and subsequent gas- and particle-phase $\mathrm{Cl}-\mathrm{VOC}$ production, Atmos. Chem. Phys., 18, 13013-13030, https://doi.org/10.5194/acp-1813013-2018, 2018.

Lewis, E. R.: An examination of Köhler theory resulting in an accurate expression for the equilibrium radius ratio of a hygroscopic aerosol particle valid up to and including relative humidity $100 \%$, J. Geophys. Res.-Atmos., 113, D03205, https://doi.org/10.1029/2007JD008590, 2008.

Liu, X., Qu, H., Huey, L. G., Wang, Y., Sjostedt, S., Zeng, L., Lu, K., $\mathrm{Wu}, \mathrm{Y}$., Hu, M., and Shao, M.: High levels of daytime molecular chlorine and nitryl chloride at a rural site on the North China Plain, Environ. Sci. Technol., 51, 9588-9595, 2017.

McCulloch, A., Aucott, M. L., Benkovitz, C. M., Graedel, T. E., Kleiman, G., Midgley, P. M., and Li, Y. F.: Global emissions of hydrogen chloride and chloromethane from coal combustion, incineration and industrial activities: Reactive Chlorine Emissions Inventory, J. Geophys. Res.-Atmos., 104, 8391-8403, 1999.

McDuffie, E. E., Womack, C. C., Fibiger, D. L., Dube, W. P., Franchin, A., Middlebrook, A. M., Goldberger, L., Lee, B. H., Thornton, J. A., Moravek, A., Murphy, J. G., Baasandorj, M., and Brown, S. S.: On the contribution of nocturnal heterogeneous reactive nitrogen chemistry to particulate matter formation during wintertime pollution events in Northern Utah, Atmos. Chem. Phys., 19, 9287-9308, https://doi.org/10.5194/acp19-9287-2019, 2019.

McNamara, S. M., Raso, A. R., Wang, S., Thanekar, S., Boone, E. J., Kolesar, K. R., Peterson, P. K., Simpson, W. R., Fuentes, J. D., and Shepson, P. B.: Springtime Nitrogen Oxide-Influenced Chlorine Chemistry in the Coastal Arctic, Environ. Sci. Technol., 53, 8057-8067, 2019.

Mielke, L., Stutz, J., Tsai, C., Hurlock, S., Roberts, J., Veres, P., Froyd, K., Hayes, P., Cubison, M., and Jimenez, J.: Heterogeneous formation of nitryl chloride and its role as a nocturnal $\mathrm{NO}_{x}$ reservoir species during CalNex-LA 2010, J. Geophys. Res.Atmos., 118, 10638-10652, 2013.

Mielke, L. H., Furgeson, A., and Osthoff, H. D.: Observation of $\mathrm{ClNO}_{2}$ in a mid-continental urban environment, Environ. Sci. Technol., 45, 8889-8896, 2011.

Mielke, L. H., Furgeson, A., Odame-Ankrah, C. A., and Osthoff, H. D.: Ubiquity of $\mathrm{ClNO}_{2}$ in the urban boundary layer of Calgary, Alberta, Canada, Can. J. Chem., 94, 414-423, 2016.
Molina, M. J. and Rowland, F. S.: Stratospheric sink for chlorofluoromethanes: chlorine atom-catalysed destruction of ozone, Nature, 249, 810-812, 1974.

Nakayama, T., Ide, T., Taketani, F., Kawai, M., Takahashi, K., and Matsumi, Y.: Nighttime measurements of ambient $\mathrm{N}_{2} \mathrm{O}_{5}, \mathrm{NO}_{2}$, $\mathrm{NO}$ and $\mathrm{O}_{3}$ in a sub-urban area, Toyokawa, Japan, Atmospheric Environment, 42, 1995-2006, 2008.

Osthoff, H. D., Roberts, J. M., Ravishankara, A. R., Williams, E. J., Lerner, B. M., Sommariva, R., Bates, T. S., Coffman, D., Quinn, P. K., Dibb, J. E., Stark, H., Burkholder, J. B., Talukdar, R. K., Meagher, J., Fehsenfeld, F. C., and Brown, S. S.: High levels of nitryl chloride in the polluted subtropical marine boundary layer, Nat. Geosci., 1, 324-328, 2008.

Osthoff, H. D., Odame-Ankrah, C. A., Taha, Y. M., Tokarek, T. W., Schiller, C. L., Haga, D., Jones, K., and Vingarzan, R.: Low levels of nitryl chloride at ground level: nocturnal nitrogen oxides in the Lower Fraser Valley of British Columbia, Atmos. Chem. Phys., 18, 6293-6315, https://doi.org/10.5194/acp18-6293-2018, 2018.

Peng, X., W. Wang, M. Xia, H. Chen, A. R. Ravishankara, Q. Li, A. Saiz-Lopez, P. Liu, F. Zhang, C. Zhang, L. Xue, X. Wang, C. George, J. Wang, Y. Mu, J. Chen, and T. Wang, An unexpected large continental source of reactive bromine and chlorine with significant impact on wintertime air quality, Natl. Sci. Rev., 8, nwaa304, https://doi.org/10.1093/nsr/nwaa304, 2020.

Phillips, G. J., Tang, M. J., Thieser, J., Brickwedde, B., Schuster, G., Bohn, B., Lelieveld, J., and Crowley, J. N.: Significant concentrations of nitryl chloride observed in rural continental Europe associated with the influence of sea salt chloride and anthropogenic emissions, Geophys. Res. Lett., 39, L10811, https://doi.org/10.1029/2012GL051912, 2012.

Phillips, G. J., Thieser, J., Tang, M., Sobanski, N., Schuster, G., Fachinger, J., Drewnick, F., Borrmann, S., Bingemer, H., Lelieveld, J., and Crowley, J. N.: Estimating $\mathrm{N}_{2} \mathrm{O}_{5}$ uptake coefficients using ambient measurements of $\mathrm{NO}_{3}, \mathrm{~N}_{2} \mathrm{O}_{5}, \mathrm{ClNO}_{2}$ and particle-phase nitrate, Atmos. Chem. Phys., 16, 13231-13249, https://doi.org/10.5194/acp-16-13231-2016, 2016.

Priestley, M., le Breton, M., Bannan, T. J., Worrall, S. D., Bacak, A., Smedley, A. R. D., Reyes-Villegas, E., Mehra, A., Allan, J., Webb, A. R., Shallcross, D. E., Coe, H., and Percival, C. J.: Observations of organic and inorganic chlorinated compounds and their contribution to chlorine radical concentrations in an urban environment in northern Europe during the wintertime, Atmos. Chem. Phys., 18, 13481-13493, https://doi.org/10.5194/acp-1813481-2018, 2018.

Qian, X., Shen, H., and Chen, Z.: Characterizing summer and winter carbonyl compounds in Beijing atmosphere, Atmos. Environ., 214, 116845, https://doi.org/10.1016/j.atmosenv.2019.116845, 2019.

Ran, L., Deng, Z., Wang, P., and Xia, X.: Black carbon and wavelength-dependent aerosol absorption in the North China Plain based on two-year aethalometer measurements, Atmos. Environ., 142, 132-144, 2016.

Riedel, T. P., Bertram, T. H., Crisp, T. A., Williams, E. J., Lerner, B. M., Vlasenko, A., Li, S. M., Gilman, J., de Gouw, J., Bon, D. M., Wagner, N. L., Brown, S. S., and Thornton, J. A.: Nitryl chloride and molecular chlorine in the coastal marine boundary layer, Environ. Sci. Technol., 46, 10463-10470, 2012. 
Riedel, T. P., Wagner, N. L., Dubé, W. P., Middlebrook, A. M., Young, C. J., Öztürk, F., Bahreini, R., VandenBoer, T. C., Wolfe, D. E., and Williams, E. J.: Chlorine activation within urban or power plant plumes: Vertically resolved $\mathrm{ClNO}_{2}$ and $\mathrm{Cl}_{2}$ measurements from a tall tower in a polluted continental setting, J. Geophys. Res.-Atmos., 118, 8702-8715, 2013.

Riedel, T. P., Wolfe, G. M., Danas, K. T., Gilman, J. B., Kuster, W. C., Bon, D. M., Vlasenko, A., Li, S.-M., Williams, E. J., Lerner, B. M., Veres, P. R., Roberts, J. M., Holloway, J. S., Lefer, B., Brown, S. S., and Thornton, J. A.: An MCM modeling study of nitryl chloride $\left(\mathrm{ClNO}_{2}\right)$ impacts on oxidation, ozone production and nitrogen oxide partitioning in polluted continental outflow, Atmos. Chem. Phys., 14, 3789-3800, https://doi.org/10.5194/acp-14-3789-2014, 2014.

Simpson, W. R., Brown, S. S., Saiz-Lopez, A., Thornton, J. A., and von Glasow, R.: Tropospheric halogen chemistry: Sources, cycling, and impacts, Chem. Rev., 115, 4035-4062, 2015.

Sommariva, R., Hollis, L. D., Sherwen, T., Baker, A. R., Ball, S. M., Bandy, B. J., Bell, T. G., Chowdhury, M. N., Cordell, R. L., and Evans, M. J.: Seasonal and geographical variability of nitryl chloride and its precursors in Northern Europe, Atmos. Sci. Lett., 19, e844, https://doi.org/10.1002/as1.844, 2018.

Tan, Z., Fuchs, H., Lu, K., Hofzumahaus, A., Bohn, B., Broch, S., Dong, H., Gomm, S., Häseler, R., He, L., Holland, F., Li, X., Liu, Y., Lu, S., Rohrer, F., Shao, M., Wang, B., Wang, M., Wu, Y., Zeng, L., Zhang, Y., Wahner, A., and Zhang, Y.: Radical chemistry at a rural site (Wangdu) in the North China Plain: observation and model calculations of $\mathrm{OH}, \mathrm{HO}_{2}$ and $\mathrm{RO}_{2}$ radicals, Atmos. Chem. Phys., 17, 663-690, https://doi.org/10.5194/acp17-663-2017, 2017.

Tham, Y. J., Wang, Z., Li, Q., Yun, H., Wang, W., Wang, X., Xue, L., Lu, K., Ma, N., Bohn, B., Li, X., Kecorius, S., Größ, J., Shao, M., Wiedensohler, A., Zhang, Y., and Wang, T.: Significant concentrations of nitryl chloride sustained in the morning: investigations of the causes and impacts on ozone production in a polluted region of northern China, Atmos. Chem. Phys., 16, 14959-14977, https://doi.org/10.5194/acp-16-14959-2016, 2016.

Thornton, J. A., Kercher, J. P., Riedel, T. P., Wagner, N. L., Cozic, J., Holloway, J. S., Dube, W. P., Wolfe, G. M., Quinn, P. K., Middlebrook, A. M., Alexander, B., and Brown, S. S.: A large atomic chlorine source inferred from mid-continental reactive nitrogen chemistry, Nature, 464, 271-274, 2010.

Wang, H., Lu, K., Chen, X., Zhu, Q., Chen, Q., Guo, S., Jiang, M., Li, X., Shang, D., and Tan, Z.: High $\mathrm{N}_{2} \mathrm{O}_{5}$ Concentrations Observed in Urban Beijing: Implications of a Large Nitrate Formation Pathway, Environ. Sci. Technol. Lett., 4, 416-420, 2017.

Wang, H., Lu, K., Guo, S., Wu, Z., Shang, D., Tan, Z., Wang, Y., Le Breton, M., Lou, S., Tang, M., Wu, Y., Zhu, W., Zheng, J., Zeng, L., Hallquist, M., Hu, M., and Zhang, Y.: Efficient $\mathrm{N}_{2} \mathrm{O}_{5}$ uptake and $\mathrm{NO}_{3}$ oxidation in the outflow of urban Beijing, Atmos. Chem. Phys., 18, 9705-9721, https://doi.org/10.5194/acp18-9705-2018, 2018.

Wang, H., Chen, X., Lu, K., Hu, R., Li, Z., Wang, H., Ma, X., Yang, X., Chen, S., and Dong, H.: $\mathrm{NO}_{3}$ and $\mathrm{N}_{2} \mathrm{O}_{5}$ chemistry at a suburban site during the EXPLOREYRD campaign in 2018, Atmos. Environ., 224, 117180, https://doi.org/10.1016/j.atmosenv.2019.117180, 2019.
Wang, H., Chen, X., Lu, K., Tan, Z., Ma, X., Wu, Z., Li, X., Liu, Y., Shang, D., and Wu, Y.: Wintertime $\mathrm{N}_{2} \mathrm{O}_{5}$ uptake coefficients over the North China Plain, Sci. Bull., 65, 765-774, 2020.

Wang, T., Tham, Y. J., Xue, L., Li, Q., Zha, Q., Wang, Z., Poon, S. C., Dubé, W. P., Blake, D. R., and Louie, P. K.: Observations of nitryl chloride and modeling its source and effect on ozone in the planetary boundary layer of southern China, J. Geophys. Res.-Atmos., 121, 2476-2489, 2016.

Wang, X., Wang, H., Xue, L., Wang, T., Wang, L., Gu, R., Wang, W., Tham, Y. J., Wang, Z., Yang, L., Chen, J., and Wang, W.: Observations of $\mathrm{N}_{2} \mathrm{O}_{5}$ and $\mathrm{ClNO}_{2}$ at a polluted urban surface site in North China: High $\mathrm{N}_{2} \mathrm{O}_{5}$ uptake coefficients and low $\mathrm{ClNO}_{2}$ product yields, Atmos. Environ., 156, 125-134, 2017.

Wang, Z., Wang, W., Tham, Y. J., Li, Q., Wang, H., Wen, L., Wang, $\mathrm{X}$., and Wang, T.: Fast heterogeneous $\mathrm{N}_{2} \mathrm{O}_{5}$ uptake and $\mathrm{ClNO}_{2}$ production in power plant and industrial plumes observed in the nocturnal residual layer over the North China Plain, Atmos. Chem. Phys., 17, 12361-12378, https://doi.org/10.5194/acp-1712361-2017, 2017.

Wen, L., Xue, L., Wang, X., Xu, C., Chen, T., Yang, L., Wang, T., Zhang, Q., and Wang, W.: Summertime fine particulate nitrate pollution in the North China Plain: increasing trends, formation mechanisms and implications for control policy, Atmos. Chem. Phys., 18, 11261-11275, https://doi.org/10.5194/acp-18-112612018, 2018.

Wild, R. J., Edwards, P. M., Bates, T. S., Cohen, R. C., de Gouw, J. A., Dubé, W. P., Gilman, J. B., Holloway, J., Kercher, J., Koss, A. R., Lee, L., Lerner, B. M., McLaren, R., Quinn, P. K., Roberts, J. M., Stutz, J., Thornton, J. A., Veres, P. R., Warneke, C., Williams, E., Young, C. J., Yuan, B., Zarzana, K. J., and Brown, S. S.: Reactive nitrogen partitioning and its relationship to winter ozone events in Utah, Atmos. Chem. Phys., 16, 573583, https://doi.org/10.5194/acp-16-573-2016, 2016.

Xia, M., Wang, W., Wang, Z., Gao, J., Li, H., Liang, Y., Yu, C., Zhang, Y., Wang, P., Zhang, Y., Bi, F., Cheng, X., and Wang, T.: Heterogeneous Uptake of $\mathrm{N}_{2} \mathrm{O}_{5}$ in Sand Dust and Urban Aerosols Observed during the Dry Season in Beijing, Atmosphere, 10, 204, https://doi.org/10.3390/atmos10040204, 2019.

Xia, M., Peng, X., Wang, W., Yu, C., Sun, P., Li, Y., Liu, Y., Xu, Z., Wang, Z., Xu, Z., Nie, W., Ding, A., and Wang, T.: Significant production of $\mathrm{ClNO}_{2}$ and possible source of $\mathrm{Cl}_{2}$ from $\mathrm{N}_{2} \mathrm{O}_{5}$ uptake at a suburban site in eastern China, Atmos. Chem. Phys., 20, 6147-6158, https://doi.org/10.5194/acp-20-6147-2020, 2020.

Xue, L. K., Saunders, S. M., Wang, T., Gao, R., Wang, X. F., Zhang, Q. Z., and Wang, W. X.: Development of a chlorine chemistry module for the Master Chemical Mechanism, Geosci. Model Dev., 8, 3151-3162, https://doi.org/10.5194/gmd-8-3151-2015, 2015.

Yan, C., Tham, Y. J., Zha, Q., Wang, X., Xue, L., Dai, J., Wang, Z., and Wang, T.: Fast heterogeneous loss of $\mathrm{N}_{2} \mathrm{O}_{5}$ leads to significant nighttime $\mathrm{NO}_{x}$ removal and nitrate aerosol formation at a coastal background environment of southern China, Sci. Total Environ., 677, 637-647, 2019.

Young, C. J., Washenfelder, R. A., Edwards, P. M., Parrish, D. D., Gilman, J. B., Kuster, W. C., Mielke, L. H., Osthoff, H. D., Tsai, C., Pikelnaya, O., Stutz, J., Veres, P. R., Roberts, J. M., Griffith, S., Dusanter, S., Stevens, P. S., Flynn, J., Grossberg, N., Lefer, B., Holloway, J. S., Peischl, J., Ryerson, T. B., Atlas, E. L., Blake, D. R., and Brown, S. S.: Chlorine as a primary 
radical: evaluation of methods to understand its role in initiation of oxidative cycles, Atmos. Chem. Phys., 14, 3427-3440, https://doi.org/10.5194/acp-14-3427-2014, 2014.

Yun, H., Wang, T., Wang, W., Tham, Y. J., Li, Q., Wang, Z., and Poon, S.: Nighttime $\mathrm{NO}_{x}$ loss and $\mathrm{ClNO}_{2}$ formation in the residual layer of a polluted region: Insights from field measurements and an iterative box model, Sci. Total Environ., 622, 727-734, 2017.

Yun, H., Wang, W., Wang, T., Xia, M., Yu, C., Wang, Z., Poon, S. C. N., Yue, D., and Zhou, Y.: Nitrate formation from heterogeneous uptake of dinitrogen pentoxide during a severe winter haze in southern China, Atmos. Chem. Phys., 18, 17515-17527, https://doi.org/10.5194/acp-18-17515-2018, 2018.

Zhang, F., Shang, X., Chen, H., Xie, G., Fu, Y., Wu, D., Sun, W., Liu, P., Zhang, C., Mu, Y., Zeng, L., Wan, M., Wang, Y., Xiao, H., Wang, G., and Chen, J.: Significant impact of coal combustion on VOCs emissions in winter in a North China rural site, Sci. Total Environ., 720, 137617, https://doi.org/10.1016/j.scitotenv.2020.137617, 2020.
Zhang, H., Li, H., Zhang, Q., Zhang, Y., Zhang, W., Wang, X., Bi, F., Chai, F., Gao, J., and Meng, L.: Atmospheric Volatile Organic Compounds in a Typical Urban Area of Beijing: Pollution Characterization, Health Risk Assessment and Source Apportionment, Atmosphere, 8, https://doi.org/10.3390/atmos8030061, 2017.

Zhou, W., Zhao, J., Ouyang, B., Mehra, A., Xu, W., Wang, Y., Bannan, T. J., Worrall, S. D., Priestley, M., Bacak, A., Chen, Q., Xie, C., Wang, Q., Wang, J., Du, W., Zhang, Y., Ge, X., Ye, P., Lee, J. D., Fu, P., Wang, Z., Worsnop, D., Jones, R., Percival, C. J., Coe, $\mathrm{H}$., and Sun, Y.: Production of $\mathrm{N}_{2} \mathrm{O}_{5}$ and $\mathrm{ClNO}_{2}$ in summer in urban Beijing, China, Atmos. Chem. Phys., 18, 11581-11597, https://doi.org/10.5194/acp-18-11581-2018, 2018.

Zhou, Y., Wang, T., Gao, X., Xue, L., Wang, X., Wang, Z., Gao, J., Zhang, Q., and Wang, W.: Continuous observations of watersoluble ions in $\mathrm{PM}_{2.5}$ at Mount Tai (1534 m a.s.1.) in centraleastern China, J. Atmos. Chem., 64, 107-127, 2009. 